DOE/OR/01-1441/V2

\title{
Oak Ridge Reservation Federal Facility Agreement Quarterly Report for the Environmental Restoration Program
}

\section{Volume 2. January-March 1996}

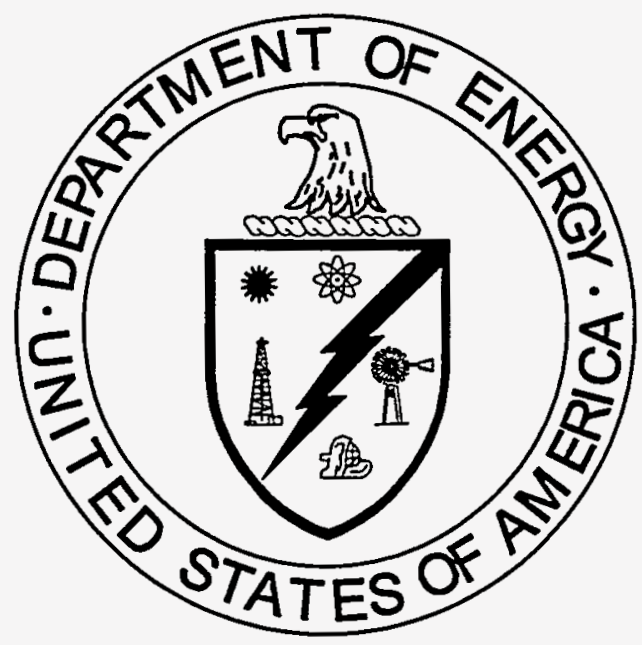

This document has been approved by the K-25 Site Technical Information Office for release to the public. Date: $4 / 26 / 96$ 


\section{Lagos \& Associates, Inc.}

contributed to the preparation of this document and should not be considered an eligible contractor for its review.

This report has been reproduced directly from the best available copy.

Available to DOE and DOE contractors from the Office of Scientific and Technical Information, P.O. Box 62, Oak Ridge, TN 37831; prices available from 423-576-8401 (fax 423-576-2865).

Available to the public from the National Technical Information Service, U.S. Department of Commerce, 5285 Port Royal Rd., Springfield, VA 22161. 


\section{PREFACE}

This Oak Ridge Reservation Federal Facility Agreement Quarterly Report for the Environmental Restoration Program was prepared to satisfy requirements for progress reporting on Environmental Restoration Program (ER) activities as specified in the Oak Ridge Reservation Federal Facility Agreement (FFA) established between the U.S. Department of Energy (DOE), the U.S. Environmental Protection Agency, and the Tennessee Department of Environment and Conservation. The reporting period covered in this document is January-March 1996.

This work was performed under Work Breakdown Structure 1.4.12.2.3.04 (Activity Data Sheet 8304). Publication of this document meets the FFA Appendix E milestone in which a quarterly activities report is required no later than 30 days following the end of the applicable reporting period. This document provides information about ER Program activities conducted on the Oak Ridge Reservation under the FFA. Specifically, it includes information on milestones scheduled for completion during the reporting period as well as scheduled for completion during the next reporting period (quarter), accomplishments of the ER Program, concerns related to program work, and scheduled activities for the next quarter. It also provides a listing of the identity and assigned tasks of contractors performing ER Program work under the FFA. 



\section{CONTENTS}

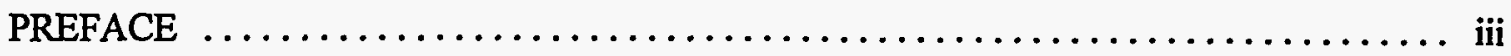

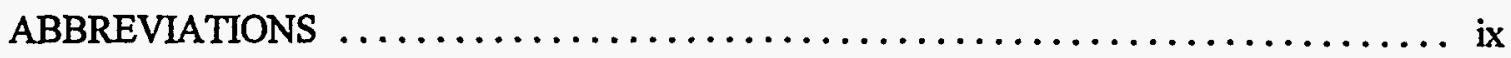

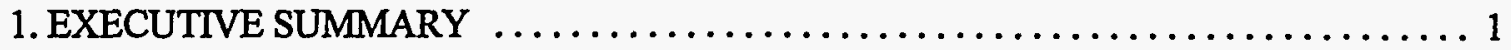

1.1 DOCUMENTS TRANSMITTED TO THE REGULATORS $\ldots \ldots \ldots \ldots \ldots \ldots \ldots 1$

1.2 DOCUMENTS PROPOSED FOR TRANSMITTAL

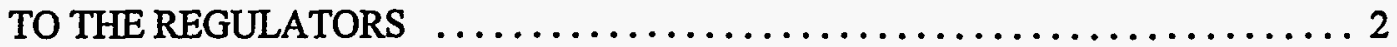

2. SIGNIFICANT ACCOMPLISHMENTS $\ldots \ldots \ldots \ldots \ldots \ldots \ldots \ldots \ldots \ldots \ldots \ldots \ldots$

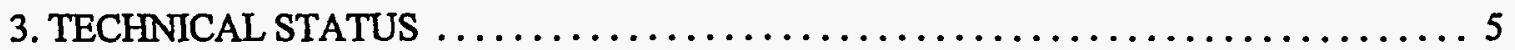

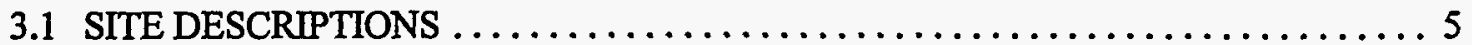

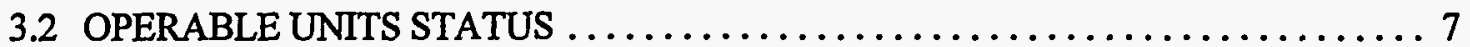

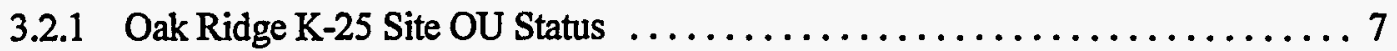

3.2.1.1 K-1070-C/D SW-31 Seep Collection and Treatment

Remedial Action ............................ 7

3.2.2 Oak Ridge National Laboratory OU Status $\ldots \ldots \ldots \ldots \ldots \ldots \ldots \ldots \ldots$

3.2.2.1 MSRE Reactive Gas Time-Critical Removal Action ........... 8

3.2.2.2 Waste Evaporator Facility ........................ 10

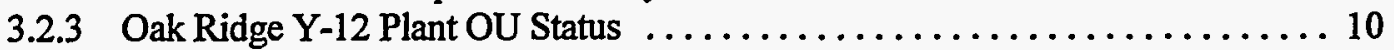

3.2.3.1 Kerr Hollow Quarry Remedial Action ................. 10

3.2.3.2 Chestnut Ridge OU $2 \ldots \ldots \ldots \ldots \ldots \ldots \ldots \ldots \ldots \ldots \ldots \ldots$

3.2.4 Other Oak Ridge Reservation Areas OU Status ................. 12

3.2.4.1 Lower East Fork Poplar Creek . . . . . . . . . . . . . . . . . . 12

3.2.4.2 Lower Watts Bar Reservoir ..................... 13

3.3 CHARACTERIZATION AREA STATUS $\ldots \ldots \ldots \ldots \ldots \ldots \ldots \ldots \ldots \ldots \ldots \ldots \ldots \ldots$

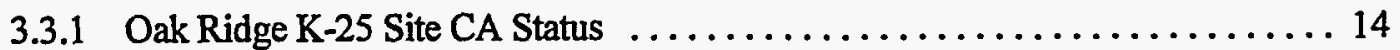

3.3.1.1 K-1070-A Burial Ground Focused RI/FS ............... 14

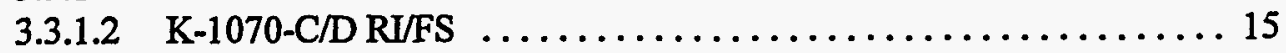

3.3.1.3 K-1007-P1 Pond Site Assessment .................. 16

3.3.1.4 K-1131/K-1410 Area Demolition and K-725 Beryllium Building

Removal (Group 1 K-25 Auxiliary Facilities Assessment) . . . . . 17

3.3.2 Oak Ridge National Laboratory CA Status $\ldots \ldots \ldots \ldots \ldots \ldots \ldots \ldots \ldots \ldots$

3.3.2.1 White Oak Creek Watershed ........................ 18

3.3.2.2 ORNL WAG 1 Gunite and Associated Tanks ............. 19

3.3.2.3 ORNL WAG 1 Surface Impoundments $\ldots \ldots \ldots \ldots \ldots \ldots \ldots \ldots$

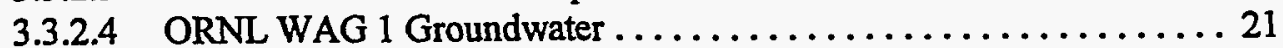

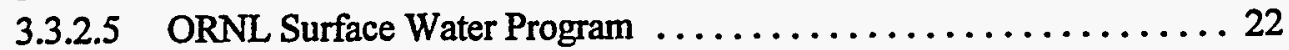

3.3.2.6 ORNL WAG 2 (White Oak Creek Embayment and Tributaries) .... 23

3.3.2.7 ORNL WAG 4 Seeps Collection and Treatment $\ldots \ldots \ldots \ldots \ldots \ldots 24$

3.3.2.8 ORNL WAG 5 OHF Tank Sludge Removal ............. 25

3.3.2.9 ORNL Area-Wide Groundwater Program $\ldots \ldots \ldots \ldots \ldots \ldots \ldots 26$

3.3.2.10 ORNL WAG 7 In Situ Vitrification $\ldots \ldots \ldots \ldots \ldots \ldots \ldots \ldots \ldots \ldots \ldots \ldots$ 
3.3.2.11 MSRE Uranium Deposit Removal Non-Time-Critical

Removal Action .......................... 28

3.3.2.12 MSRE Fuel Salt Remedial Project .................... 29

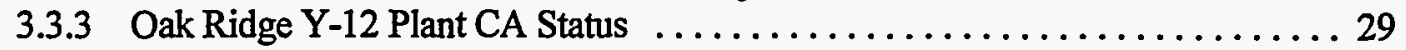

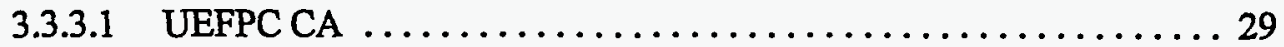

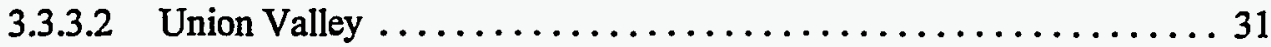

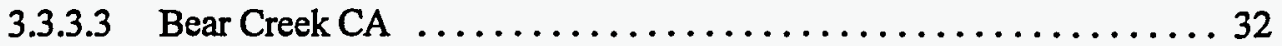

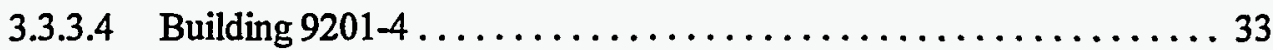

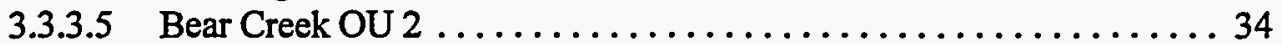

3.3.4 Other Oak Ridge Reservation Areas CA Status ................ 35

3.3.4.1 Clinch River/Poplar Creek ......................... 35

3.4 REMEDIAL SITE EVALUATION AREA STATUS $\ldots \ldots \ldots \ldots \ldots \ldots \ldots \ldots \ldots \ldots$

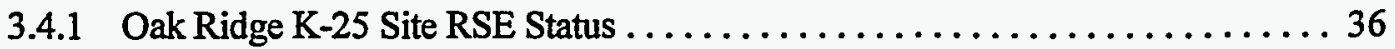

3.4.1.1 K-901-A Holding Pond Site Evaluation ................ 36

3.4.1.2 K-25 Site Groundwater Remedial Site Evaluation . . . . . . . . . 37

3.4.2 Oak Ridge National Laboratory RSE Status $\ldots \ldots \ldots \ldots \ldots \ldots \ldots \ldots \ldots$

3.4.2.1 ORNL WAG 10 Hydrofracture Wells Remedial

Site Evaluation Area $\ldots \ldots \ldots \ldots \ldots \ldots \ldots \ldots \ldots \ldots \ldots \ldots$

3.4.2.2 ORNL No Further Investigation (NFI) Areas $\ldots \ldots \ldots \ldots \ldots \ldots . \ldots 38$

3.4 .3 Oak Ridge Y-12 Plant RSE Status ............................ 39

3.4.4 Other Oak Ridge Reservation Areas RSE Status $\ldots \ldots \ldots \ldots \ldots \ldots \ldots \ldots . \ldots . \ldots$

3.4.4.1 Freels Bend Area ................................ 39

3.5 REMOVAL SITE EVALUATION AREA STATUS $\ldots \ldots \ldots \ldots \ldots \ldots \ldots \ldots \ldots$

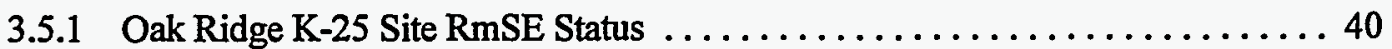

3.5.2 Oak Ridge National Laboratory RmSE Status $\ldots \ldots \ldots \ldots \ldots \ldots \ldots \ldots \ldots 40$

3.5.2.1 Nuclear Material and Facility Stabilization Program . . . . . . . 40

3.5.3 Oak Ridge Y-12 Plant RmSE Status ..................... 44

3.5.4 Other Oak Ridge Reservation Areas RmSE Status $\ldots \ldots \ldots \ldots \ldots \ldots \ldots . \ldots 4$

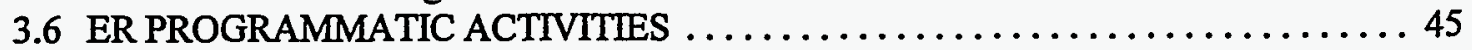

3.6.1 Oak Ridge Environmental Information System ................ 45

3.6.2 Remote Sensing and Special Surveys Program $\ldots \ldots \ldots \ldots \ldots \ldots \ldots \ldots$

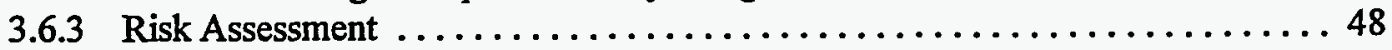

3.6.4 Federal Facility Agreement Implementation $\ldots \ldots \ldots \ldots \ldots \ldots \ldots \ldots \ldots . \ldots \ldots$

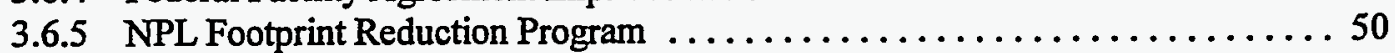

3.7 LIQUID LOW-LEVEL WASTE TANK STATUS $\ldots \ldots \ldots \ldots \ldots \ldots \ldots \ldots \ldots \ldots$

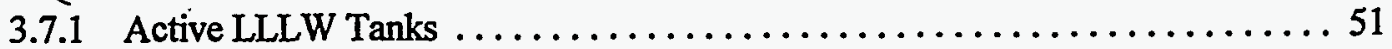

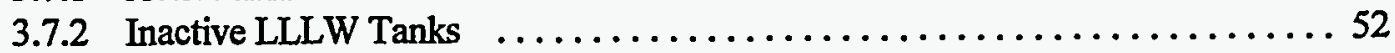

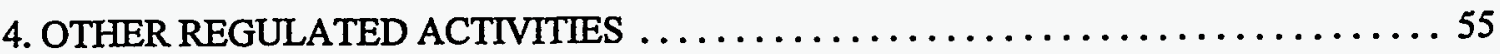

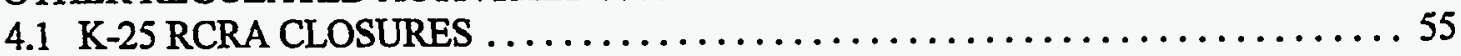

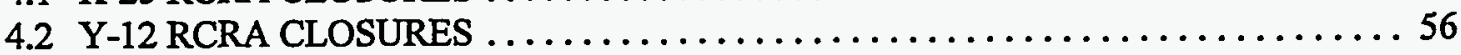

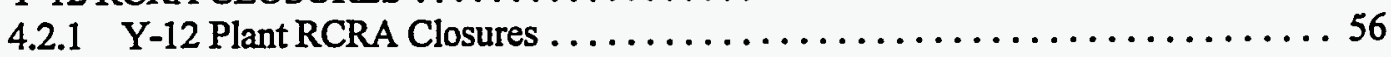

4.2.2 Kerr Hollow Quarry RCRA Closure $\ldots \ldots \ldots \ldots \ldots \ldots \ldots \ldots \ldots \ldots \ldots . \ldots \ldots$

4.3 REDUCTION OF MERCURY IN PLANT EFFLUENTS . . . . . . . . . . 58

5. REMEDIAL ACTION CONTRACTOR ASSIGNMENTS $\ldots \ldots \ldots \ldots \ldots \ldots \ldots \ldots \ldots 6$

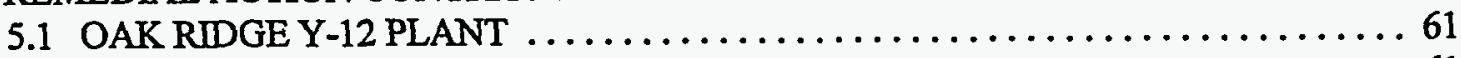

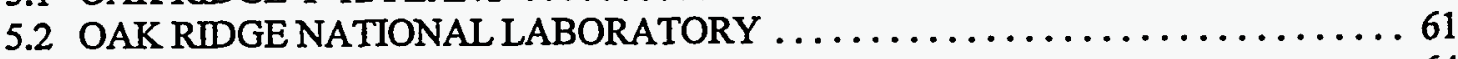

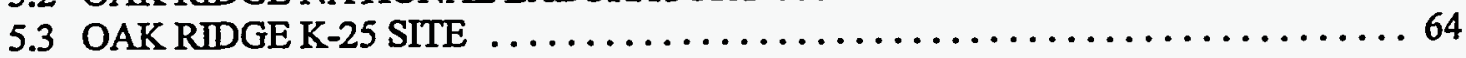


5.4 OTHER OAK RIDGE RESERVATION AREAS $\ldots \ldots \ldots \ldots \ldots \ldots \ldots \ldots \ldots \ldots$

5.5 ENERGY SYSTEMS ER CENTRAL DIVISION $\ldots \ldots \ldots \ldots \ldots \ldots \ldots \ldots \ldots \ldots 6$

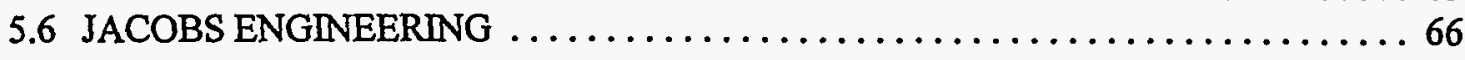




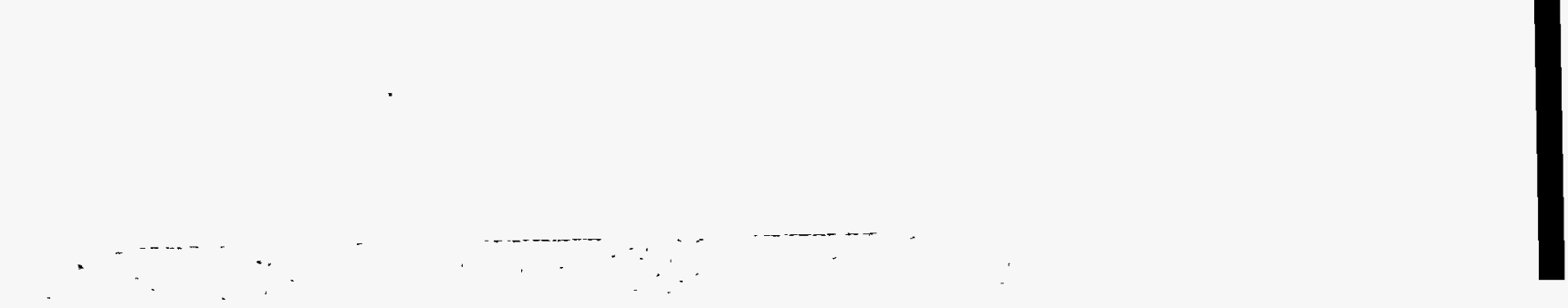




\section{ABBREVIATIONS}

\begin{tabular}{|c|c|}
\hline AM & Action Memorandum \\
\hline AOC & Area of Concern \\
\hline $\mathrm{CA}$ & Characterization Area \\
\hline CERCLA & Comprehensive Environmental Response, Compensation, and Liability Act \\
\hline $\mathrm{D} \& \mathrm{D}$ & decontamination and decommissioning \\
\hline $\mathrm{DOE}$ & U.S. Department of Energy \\
\hline DOE-ORO & DOE-Oak Ridge Operations Office \\
\hline $\mathrm{EE} / \mathrm{CA}$ & Engineering Evaluation/Cost Analysis \\
\hline EFPC & East Fork Poplar Creek \\
\hline Energy Systems & Lockheed Martin Energy Systems, Inc. \\
\hline $\mathrm{EPA}$ & U.S. Environmental Protection Agency \\
\hline ER & Environmental Restoration \\
\hline FFA & Federal Facility Agreement \\
\hline FS & Feasibility Study \\
\hline GAAT & Gunite and Associated Tanks \\
\hline ISV & in situ vitrification \\
\hline LEFPC & Lower East Fork Poplar Creek \\
\hline LLLW & liquid low-level (radioactive) waste \\
\hline MSRE & Molten Salt Reactor Experiment \\
\hline NFI & No Further Investigation \\
\hline NPDES & National Pollutant Discharge Elimination System \\
\hline NPL & National Priorities List \\
\hline OHF & Old Hydrofracture Facility \\
\hline OREIS & Oak Ridge Environmental Information System \\
\hline ORNL & Oak Ridge National Laboratory \\
\hline ORR & Oak Ridge Reservation \\
\hline OU & Operable Unit \\
\hline PCB & polychlorinated biphenyl \\
\hline RA & remedial action \\
\hline RCRA & Resource Conservation and Recovery Act \\
\hline RI & Remedial Investigation \\
\hline $\mathrm{RI} / \mathrm{FS}$ & Remedial Investigation/Feasibility Study \\
\hline RMPE & Reduction of Mercury in Plant Effluents \\
\hline RmSE & Removal Site Evaluation Areas \\
\hline ROD & Record of Decision \\
\hline RSE & Remedial Site Evaluation Areas \\
\hline SCF & South Campus Facility \\
\hline TDEC & Tennessee Department of Environment and Conservation \\
\hline UEFPC & Upper East Fork Poplar Creek \\
\hline WAG & Waste Area Grouping \\
\hline WOC & White Oak Creek \\
\hline
\end{tabular}




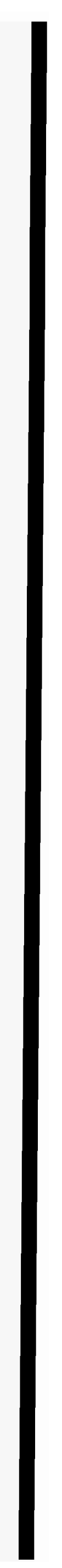




\section{EXECUTIVE SUMMARY}

This quarterly progress report satisfies requirements for the Environmental Restoration (ER) Program that are specified in the Oak Ridge Reservation (ORR) Federal Facility Agreement (FFA) established between the U.S. Department of Energy (DOE), the U.S. Environmental Protection Agency (EPA), and the Tennessee Department of Environment and Conservation (TDEC). The reporting period covered herein is January through March 1996 (second quarter of FY 1996).

Sections 1.1 and 1.2 provide, respectively, the milestones scheduled for completion during the reporting period and a list of documents that have been proposed for transmittal during the following quarter but have not been approved as FY 1996 commitments.

\subsection{DOCUMENTS TRANSMITTED TO THE REGULATORS}

The following documents were transmitted to the regulators during the second quarter of FY 1996 and can be requested from the Information Resource Center in Oak Ridge.

- Engineering Evaluation/Cost Analysis for Uranium Deposit Removal at the Molten Salt Reactor Experiment (DOE/OR/02-1439\&D1)

- Public Involvement Plan for the Oak Ridge Reservation (DOE/OR/01-1445\&D1)

- Engineering Evaluation/Cost Analysis for the Old Hydrofracture Facility Tanks at the Oak Ridge National Laboratory (DOE/OR/02-1450\&D1)

- Interim Proposed Plan for Union Valley (DOE/OR/02-1452\&D1)

- Remedial Design Report for Chestnut Ridge OU 2 (DOE/OR/01-1457\&D1)

- Risk Assessment Pathway/Transport Modeling for the Gunite and Associated Tanks (DOE/OR/02-1454\&D1)

- Phase I Remedial Design Report and Remedial Action Work Plan for the Lower East Fork Poplar Creek Operable Unit (DOE/OR/01-1448\&D1)

- K-1070 C/D Classified Burial Ground Proposed Plan (DOE/OR/02-1399\&D1)

- Proposed Plan for the Surface Impoundments Operable Unit at WAG 1 (DOE/OR/02-1427\&D1)

- Action Memorandum for the WAG 4 Seeps at Oak Ridge National Laboratory, Oak Ridge, Tennessee (DOE/OR/02-1440\&D1)

- WAG 5 Old Hydrofracture Facility Tank Sludge Removal Engineering Evaluation/Cost Analysis (DOE/OR/01-1450\&D1) 
Regulatory Commitment Status

\begin{tabular}{lcc}
\hline \multicolumn{1}{c}{ Document title } & $\begin{array}{c}\text { Appendix E } \\
\text { commitment date }\end{array}$ & Transmittal date \\
\hline WAG 4 Seeps Action Memorandum & $1 / 4 / 96$ & $1 / 3 / 96$ \\
K-1070 C/D Classified Burial Ground Proposed Plan & $1 / 16 / 96$ & $1 / 15 / 96$ \\
Surface Impoundments Proposed Plan & $2 / 9 / 96$ & $2 / 6 / 96$ \\
Phase I Remedial Design Report and Remedial Action Work & & \\
$\begin{array}{l}\text { Plan for the Lower East Fork Poplar Creek } \\
\text { Operable Unit }\end{array}$ & $2 / 15 / 96$ & $2 / 15 / 96$ \\
MSRE EE/CA for Uranium Deposit Removal & $2 / 29 / 96$ & $2 / 27 / 96$ \\
Union Valley Proposed Plan & $3 / 15 / 96$ & $3 / 14 / 96$ \\
Public Involvement Plan for the Oak Ridge Reservation & $3 / 15 / 96$ & $3 / 13 / 96$ \\
$\begin{array}{l}\text { Remedial Design Report for Operable Unit 2, Chestnut } \\
\text { Ridge Filled Coal Ash Pond }\end{array}$ & & \\
EE/CA for the Old Hydrofracture Facility Tanks & $3 / 19 / 96$ & $3 / 18 / 96$ \\
Risk Assessment Pathway/Transport Modeling for the Gunite & $4 / 30 / 96$ & $3 / 15 / 96$ \\
and Associated Tanks & & $3 / 29 / 96$ \\
\hline
\end{tabular}

\subsection{DOCUMENTS PROPOSED FOR TRANSMITTAL TO THE REGULATORS}

The following documents have been proposed for transmittal to the regulators during the third quarter of FY 1996.

- Record of Decision for Bear Creek Valley Operable Unit 2 (Spoil Area I and SY-200 Yard) at the Oak Ridge Y-12 Plant

- Oak Ridge Reservation Site Management Plan for the Environmental Restoration Program (DOE/OR/1001/R4) (DOE requested extension of the FFA milestone date of April 5, 1996, to June 28, 1996)

- Engineering Evaluation/Cost Analysis for the K-1410/1131 Area Demolition (Group $1 \mathrm{~K}-25$ Auxiliary Facilities Assessment)

- Lower East Fork Poplar Creek Phase II Remedial Design Report

- Gunite and Associated Tanks Remedial Investigation Addendum Report

- $\quad K-25$ Auxiliary Area Engineering Evaluation/Cost Analysis

- Clinch River/Poplar Creek Proposed Plan

- Chestnut Ridge OU2 Remedial Action Work Plan

- K-25 Groundwater Remedial Site Evaluation

- Active Liquid Low-Level (Radioactive) Waste (LLLW) Tanks Implementation Plan and Structural Integrity Assessment of Category C Tanks and Pipelines 


\section{SIGNIFICANT ACCOMPLISHMENTS}

The following significant accomplishments are noted for the ER Program during the second quarter of FY 1996.

- The Chestnut Ridge Operable Unit (OU) 2 Record of Decision (ROD) was submitted for approval 4 months ahead of schedule. Approval from EPA and TDEC has been received. This is a significant accomplishment given the major changes made to the alternative components and associated cost estimate revisions from the earlier version of the ROD. Continuing this trend, subsequent compression of the remedial design and remedial action (RA) schedules should result in an overall savings of approximately 7 years for the project, which is estimated to reflect a cost savings of over $\$ 2$ million.

- Concurrence was provided by TDEC on granting the No Further Investigation (NFI) status for the following areas:

- Ca-45 Tagged Trees

- Technetium-95m Contaminated Soil and Plants

- Technetium-95m Uptake Studies

- Hg-197 Tagged Stream

- C-14 Efflux in Yellow Poplar Stand

- Hg-203 Tagged Stream

- C-14 Allocation in White Pine Trees

- Zn-65 Tagged Red Oak Seedlings

- C-14 Sucrose Inoculation of Oak and Pine Trees

- C-14 Maintenance Respiration Study Site

- H-3 Contaminated Trees

- A public meeting was held February 15 at Oak Ridge Associated Universities to discuss the Programmatic Impact Statement on managing depleted uranium hexafluoride cylinders at the Oak Ridge K-25 Site.

- Site Specific Advisory Board meetings were held during the quarter on the following schedule:

- January 17 and 24-Organization and bylaws.

- February 8 and 22-Environmental management integrated priority list (discussion of the development of the list and in-depth discussion of ORR projects.

- February 21 - General business meeting.

- March 13-FY 1998 budget prioritization for ORR DOE environmental management projects.

- March 18-Discussion of the Programmatic Environmental Assessment for Proposed Privatization of Treatment and Disposal of DOE ORR LLLW Waste. The public comment period for the environmental assessment was February 29-March 29. 
- In January, a press release was issued announcing the availability of the Common Ground report; copies were mailed to stakeholders who had participated in the process, and copies were delivered to local officials.

- Community Relations played a major role in the successful 2010 Workshop, which drew more than 250 people from approximately 100 companies to Oak Ridge April 2-4 to explore reindustrialization of the K-25 Site and one Y-12 Plant facility. ER staff were responsible for nationwide advertising, direct mailing, 11 fact sheets, posters, and most conference logistics. Early responses from evaluation forms were favorable. Parts of the conference were covered by the Oak Ridger and the Knoxville News-Sentinel.

- The draft Resource Conservation and Recovery Act (RCRA) postclosure permit for Kerr Hollow Quarry has been issued for review. The public comment period closes May 13, 1996.

- To facilitate reuse of buildings and equipment at the Oak Ridge K-25 Site, an advertisement was made available via the Lockheed Martin Energy Systems, Inc., (Energy Systems) public server [http://www.ornl.gov/mmes.html] on the World Wide Web. The buildings included in this initial advertisement are $\mathrm{K}-1200 \mathrm{C} \& \mathrm{~N}, \mathrm{~K}-220$, and $\mathrm{K}-1037$. Each building has pertinent information included, such as size, construction, utilities, special features and equipment, exterior photographs, a map showing the building location on the K-25 Site, etc. Additional buildings will be added to this advertisement as well as photographs of equipment and interior views of the buildings. 


\section{TECHINICAL STATUS}

This section provides the accomplishments of the ER Program during the second quarter of FY 1996 at the ORR. This quarterly report has been recategorized to reflect the organization of Appendix C of the FFA. In this organization, Areas of Concern (AOCs) are inactive units or areas (i.e., units or areas not currently in use and for which it has been determined that no future use is planned) at which a release or threatened release of hazardous substances, pollutants, or contaminants exists. OUs are activities defined in approved decision documents, such as an AM or a ROD. Characterization Areas (CAs) include AOCs that have undergone initial review or study and for which it has been determined that additional action under the Comprehensive Environmental Response, Compensation, and Liability Act (CERCLA) is appropriate (e.g., additional study, nontime-critical removal action, etc.). Remedial Site Evaluation Areas (RSEs) include AOCs where sufficient information exists to conclude that the potential for contamination exists; however, insufficient information exists to determine if further CERCLA characterization is warranted. Removal Site Evaluation Areas (RmSEs) include AOCs that meet the criteria for evaluation under CERCLA (i.e., area is inactive and hazardous substances may have been released), but insufficient information exists to determine if a removal or RA is necessary. ER Program activities conducted in the second quarter of FY 1996 are presented in this report relative to the category of AOCs with which they are associated and are discussed in Sects. 3.1-3.7.

Section 3.7 also includes the technical status of LLLW tank systems. These tanks and tank systems are managed subject to provisions under the FFA Appendix F for the Category A, B, and C tanks and in Appendix C for the Category D tanks.

\subsection{SITE DESCRIPTIONS}

\section{Oak Ridge K-25 Site}

The K-25 Site was built as part of the Manhattan Project during World War II to supply enriched uranium for nuclear weapons production. Construction of the K-25 Site started in 1943, and Building K-25, the first diffusion facility for large-scale separation of ${ }^{235} \mathrm{U}$, was fully operable by August 1945. Additional buildings involved in the enrichment process were operable by 1956 . In response to the national postwar nuclear emphasis, plant operations were modified to include the production of uranium compatible with reactors used to generate electric power. Because of the declining demand for enriched uranium, the enrichment process was placed on standby in 1985 and shut down in 1987. The K-25 Site now has a multipurpose mission that includes serving as the location of many contractor central staff functions, operating waste treatment facilities, serving as a center for applied technology, and supporting the development of the Advanced Vapor Laser Isotope Separation uranium enrichment technology.

The K-25 Site is considered one watershed because of its location near the confluence of Poplar Creek and Clinch River and because of the large areas of cut and fill that were excavated during the construction of the plant. Specific sources or groups of sources within that watershed are the subject of environmental cleanup projects. 


\section{Oak Ridge National Laboratory}

ORNL occupies approximately 3560 acres in Melton Valley and Bethel Valley, 10 miles southwest of downtown Oak Ridge, Tennessee. ORNL's missions are to conduct applied research and engineering development in support of DOE programs in nuclear fusion and fission, energy conservation, fossil fuels, and other energy technologies and to perform basic scientific research in selected areas of the physical, life, and environmental sciences. The laboratory was built in 1943 as part of the World War II Manhattan Project. Its original mission was to produce and chemically separate the first gram quantities of plutonium as part of the national effort to produce the atomic bomb.

\section{Oak Ridge Y-12 Plant}

The original mission of the Oak Ridge Y-12 Plant, built adjacent to the city of Oak Ridge in 1943 as part of the Manhattan Project, was to separate the fissionable isotope of uranium $\left({ }^{235} \mathrm{U}\right)$ by the electromagnetic process. Since the discontinuation of this process and until 1993, the facility evolved to support highly sophisticated manufacturing and development engineering associated with the production and fabrication of nuclear weapons components. Currently, the work force is refocusing the unique technical capabilities and expertise at the facility to provide (1) weapons dismantlement and storage, (2) enriched uranium material storage and management, (3) weapons process technology and development support, (4) renovation or decontamination and decommissioning (D\&D) of standby or shut down buildings, (5) transfer of DOE-developed technology to enhance the competitiveness of the nation's industry in world-wide markets, and (6) maintenance and support of the National Security Program Office for DOE.

An additional facility priority is the cleanup or mitigation of environmental pollution resulting from past waste management practices on portions of the 800 -acre site. The RA strategy integrates the numerous applicable federal and state regulations for efficient compliance and approaches both investigation and remediation efforts on a watershed basis. Three watersheds, or hydrogeologic regimes, have been identified at the facility: (1) Bear Creek, (2) Upper East Fork Poplar Creek (UEFPC), and (3) Chestnut Ridge.

\section{Other Oak Ridge Reservation Areas}

These areas are on the border of and help to define the boundary of the ORR National Priorities List (NPL) area and consist of the Clinch River/Poplar Creek area, Lower Watts Bar Reservoir, Lower East Fork Poplar Creek (LEFPC), and Oak Ridge Associated Universities' SCF and Freels Bend Area.

Clinch River/Poplar Creek focuses on the portions of Poplar Creek and the Clinch and Tennessee rivers that may have been adversely affected by contaminants released from ORR from the mid-1940s to the present. Melton Hill Reservoir and Clinch River downstream from Melton Hill Dam form the southern and eastern boundaries of the reservation.

Watts Bar Reservoir is located on the Tennessee River just below its confluence with Clinch River and is the first impoundment downstream of ORR. Contaminants released from the reservation into these water systems include a variety of radionuclides, metals, and organic compounds, with polychlorinated biphenyls (PCBs) and cesium being of particular concern. The PCBs are identified as a concern through fish ingestion, and the cesium is a risk only if deep-channel sediments are dredged and the spoils placed on land. 
LEFPC extends from the outfall of Lake Reality at the Y-12 Plant boundary, through the city of Oak Ridge, and downstream to the stream's confluence with Poplar Creek. It consists of a 23-km stream and associated 550-acre floodplain. LEFPC became contaminated with mercury and trace levels of other metals, organics, and radionuclides originating within the Y-12 Plant.

Oak Ridge Associated Universities' SCF is located within the city limits of Oak Ridge and is bounded by Bethel Road, State Highway 62, Haw Ridge, and Clinch River. SCF was originally established in 1945 to study the accidental irradiation of cattle that occurred during the test of the first atomic bomb near Alamogordo, New Mexico. Soon its scope included studies on the introduction and migration of radioisotopes in the food chain. The primary contaminant of concern is a small trichloroethene plume located on the site.

The Freels Bend Area was used to support research conducted on SCF. Controlled herds of some animals were maintained on pasture land there with ancillary barns and outbuildings. In addition, a Low-Dose-Rate Facility and a Variable-Dose-Rate Facility were located on the site, along with three reported animal burial sites.

\title{
3.2 OPERABLE UNITS STATUS
}

Upon completion and approval of a decision document (e.g., AM, ROD), clean up or risk mitigation is initiated. When the decision document is signed, the action is designated as an OU in Appendix C of the FFA. Activities for an OU are governed by the terms and conditions of the decision document.

\subsubsection{Oak Ridge K-25 Site OU Status}

\subsubsection{K-1070-C/D SW 31 Seep Collection and Treatment Remedial Action}

\section{Area of Concern}

\author{
K-1070-C/D Classified Burial Ground
}

\section{Description}

This project involves implementing an interim RA for the K-1070 Leachate Seep (SW-31) to reduce risk to human health and the environment. The seep appeared after an attempted reclamation of the area bordering the west end of the K-1070-C/D Burial Ground, which was swampy and had an unpleasant smell. The K-1070-C/D Classified Burial Ground was used to dispose of a variety of equipment and waste, including solvents and hazardous chemicals. The RA chosen involves pretreatment to remove iron, air stripping the discharged water to remove volatile contaminants, then carbon filtration (polishing) to remove PCBs. Implementation of the RA took place in two phases. Phase 1 involved construction of a collection facility and transport of the spring water to the Y-12 Groundwater Treatment Facility for treatment. Phase 2 involved the modification of the K-25 Central Neutralization Facility to add unit processes enabling the treatment of organic compounds. After the completion of Phase 2, the spring water will be treated on site at the K-25 Central Neutralization Facility.

Work in FY 1996 will include the completion of construction of the Phase 2 modifications at the K-25 Central Neutralization Facility and continued collection, transportation, and treatment at the Y-12 Groundwater Treatment Facility. After completion of the Phase 2 modifications, the new 
system will undergo test and check out and be brought into operation. A RA report will then be prepared documenting the completion of the action.

\section{Accomplishments}

Phase I: Installation of new flanged piping from the collection sump to the storage tanks was completed. Use of a check valve (to allow for draining) in the new pipe run allowed for elimination of heat tracing for this section of piping.

Phase II: Construction activity at the Central Neutralization Facility continued. All major procurement items have been received from Encotech (the major equipment vendor). A meeting of the Test \& Checkout team was held on January 29, 1996, to review plans for functional and integrated testing after completion of construction.

\section{Concerns}

None.

\section{Scheduled Activities for Next Quarter}

Phase I: A detailed operational summary on the recovery and treatment system will be prepared for inclusion in the ORR Remediation Effectiveness Report.

Phase II: Complete construction of the Central Neutralization Facility upgrade and bring the system into operation.

\subsubsection{Oak Ridge National Laboratory OU Status}

\subsubsection{MSRE Reactive Gas Time-Critical Removal Action}

\section{Area of Concern}

Molten Salt Reactor Experiment (MSRE) Reactor Building [Main Reactor, Reactor Cells, Radiator Stack, Blower House, and Vent House (7503)]

\section{Description}

MSRE is located in Building 7503 in WAG 8, which is situated in Melton Valley. It was part of the Atomic Energy Commission's Molten Salt Reactor Program, which was built to investigate the concept for central power station applications. The reactor first went critical on June 1,1965, and was shut down on December 12, 1969. A surveillance and maintenance program was initiated and continues on the shutdown facility. Elevated radiation readings detected in June 1994 indicated migration of radioactive contamination outside the fuel drain tank cells. Subsequent analyses and tests showed evidence of uranium hexafluoride $\left(\mathrm{UF}_{6}\right)$ in the Auxiliary Charcoal Bed, located in the Charcoal Bed Cell.

A time-critical removal action program was initiated in July 1994 based on the findings that radionuclides had migrated outside the fuel tank drain cells. In October and November 1994, water was removed from the Auxiliary Charcoal Bed Cell, and several other stabilization measures were performed in advance of the submittal of the AM by letter, dated May 12, 1995. Stabilization measures included installation of a criticality alarm, grouting of the cell overflow line, installation 
of an isolation valve in the cell ventilation line, isolation of the cell drain line, installation of sealed plugs into penetrations in the cell shield plug, and inserting the cell atmosphere by filling with carbon dioxide. EPA has acknowledged and accepted the actions taken. The remaining items to be performed upon approval of the AM include (1) the implementation of a chemical trapping system for the removal of reactive gases from the off-gas system, (2) installation of a water monitoring and removal system and permanent pressure and monitoring instrumentation, and (3) a permanent weather protection structure.

The removal of potentially reactive $\mathrm{UF}_{6}$ and fluorine gases from the off-gas system, the Auxiliary Charcoal Bed, and the Fuel Drain Tanks will complete the removal action. A shielded chemical trapping system is proposed to collect and trap the reactive gases. Once the gases are chemically adsorbed onto reactive pellets as a solid, the fluorine can be properly managed as an aluminum trifluoride waste material, and the $\mathrm{UF}_{6}$ will be managed as a product in a storage facility at ORNL. The stored $\mathrm{UF}_{6}$ must be processed and converted to a stable uranium oxide to ensure long-term stability. Operation of the reactive gas collection system is expected to continue until the fuel salt has been removed from the facility.

The public and employees were informed throughout the process of discovery, the performance of the stabilization measures, and the scoping of the removal action. A senior review board of independent, recognized nuclear industry experts assessed the MSRE removal action in February 1995. The board noted that actions at the facility that have already been taken, are currently in progress, or are planned for the near future have been and will be effective in reducing the risks at MSRE.

\section{Accomplishments}

Installation of the interim purge-and-vent trap system, including the tubing, ventilation ducts, and other support hardware for removal of the reactive gases, is about $20 \%$ complete. The critical components of the system are being performance tested prior to installation. The performance tests establish the operational parameters for reactive gas removal as well as providing assurance of proper operation. Trap monitoring systems are also being checked during these tests to resolve any operational issues before final installation. The performance testing program is about $50 \%$ complete.

\section{Concerns}

None.

\section{Scheduled Activities for Next Quarter}

Final testing and readiness review evaluations are scheduled for the interim vent and trap system. 


\subsubsection{Waste Evaporator Facility}

Area of Concern

Waste Evaporator Facility

\section{Description}

Building 3506 (Waste Evaporator Facility) is located adjacent to the South Tank Farm in the main plant area. Building 3506 operated as an evaporator from 1949 to 1954 , and after decontamination it was used as an experimental facility to demonstrate contaminated waste incineration. The primary project objective is the demolition of the above-grade portions of the facility. This action would remove an obstacle inhibiting access in the South Tank Farm and would facilitate the continued remedial activities at the Gunite and Associated Tanks (GAAT) CA. This $\mathrm{D} \& \mathrm{D}$ activity is being conducted as a non-time-critical removal action under CERCLA.

\section{Accomplishments}

Demolition work was initiated.

\section{Concerns}

None.

\section{Scheduled Activities for Next Quarter}

Removal actions will be completed.

Preparation of the Removal Action Report will begin.

\subsubsection{Oak Ridge Y-12 Plant OU Status}

\subsubsection{Kerr Hollow Quarry Remedial Action}

\section{Area of Concern}

\section{Kerr Hollow Quarry}

\section{Description}

Kerr Hollow Quarry was a former rock and gravel quarry that was abandoned in the late 1940s when it filled with water. From at least 1951 until 1988, the Y-12 Plant and ORNL used Kerr Hollow Quarry for the treatment of water-reactive and corrosive materials and potentially explosive chemicals and for the disposal of empty compressed gas cylinders when personnel safety was of concern. Kerr Hollow Quarry was not intended for use as a hazardous waste storage or disposal facility but was used as a treatment facility as registered on the RCRA Part A permit. The facility was placed in interim status under RCRA, and treatment operations ceased in 1988. Kerr Hollow Quarry discharged through Outfall 301, and this outfall was monitored in accordance with National Pollutant Discharge Elimination System (NPDES) Permit TN 0002968. The permit required monitoring the Kerr Hollow Quarry outfall following a treatment operation, with results reported quarterly to TDEC. A RCRA closure was completed on this project, which included underwater breaching of containers 
to ensure complete reaction of reactive materials and removal of all visible containers from the quarry. Based on the actions taken under RCRA, no additional investigations were conducted under CERCLA, and a CERCLA ROD was approved in the fourth quarter of FY 1995. The ROD requires surface water monitoring at the former NPDES Outfall 301 . This monitoring will be conducted semiannually. In addition, the ROD defers groundwater monitoring requirements to the RCRA postclosure permit, which was recently issued for review. Until the permit is issued, detection monitoring at the surrounding groundwater wells will continue quarterly. In the future, summarized monitoring results will be reported in the annual Remediation Effectiveness Report for the ORR and in the Chestnut Ridge Hydrogeologic Regime Groundwater Quality Report.

\section{Accomplishments}

Monitoring, as required by the ROD, was begun in the second quarter of FY 1996.

\section{Concerns}

None.

\section{Scheduled Activities for Next Quarter}

Continue sampling and analysis as required by the ROD.

A detailed summary of monitoring data will be prepared for inclusion in the ORR Remediation Effectiveness Report.

\subsubsection{Chestnut Ridge OU 2}

Area of Concern

Filled Coal Ash Pond, Upper McCoy Branch

\section{Description}

Chestnut Ridge OU 2 consists of the Filled Coal Ash Pond and Upper McCoy Branch. The Filled Coal Ash Pond is situated within the McCoy Branch watershed approximately 0.5 mile south of the Y-12 Plant. The pond was constructed in 1955 to serve as a settling basin for coal ash from the Y-12 steam plant. By 1967 the pond had filled, spilling sediments directly into McCoy Branch. From 1967 to 1989, ash was carried within McCoy Branch to Rogers Quarry, approximately 0.5 mile downstream of the Coal Ash Pond.

Impacts to surface water, stream sediments, and groundwater from metals, including uranium and major ions, are of concern. Biomonitoring of aquatic organisms in McCoy Branch and Rogers Quarry has shown a potential biological impact from the ash pond operations.

A Proposed Plan and a ROD have been prepared for this site. The preferred alternative is stabilization of the dam and relocation of a wetlands at the base of the dam, which will be disrupted as a result of construction. An accelerated schedule for implementation of the preferred alternative

has been discussed with EPA and TDEC. This accelerated schedule calls for completion of construction activities in October 1996. This is accelerated by more than 3 years relative to the baseline schedule and results in a cost saving of more than $\$ 800 \mathrm{~K}$. A letter was transmitted 
requesting regulatory approval of the expedited schedule. Concurrence was received from TDEC in December 1995.

In addition, a letter and attached schedule were issued to EPA and TDEC in December 1995 in lieu of submittal of a Remedial Design Work Plan.

\title{
Accomplishments
}

Signed copies of the ROD (DOE/OR/02-1410\&D2) were transmitted to the regulators by letter dated March 6, 1996.

The Remedial Design Report for Chestnut Ridge OU 2 (DOE/OR/01-1457\&D1) was submitted to the regulators.

\section{Concerns}

None.

\section{Scheduled Activities for Next Quarter}

Receive comments on the D1 remedial design submittal.

Continue preparation of the remedial design package.

\subsubsection{Other Oak Ridge Reservation Areas OU Status}

\subsubsection{Lower East Fork Poplar Creek}

\author{
Area of Concern
}

\section{LEFPC}

\section{Description}

The LEFPC OU extends from the outfall at Lake Reality at the Y-12 Plant boundary downstream to the stream's confluence with Poplar Creek. More than 20 tributaries and treated effluent from the Oak Ridge Sewage Treatment Plant flow into the creek. The LEFPC site consists of the 23-km stream and an associated 550-acre floodplain.

Beginning in 1952, the Y-12 Plant began production-scale separation of lithium isotopes, which required the use of millions of kilograms of mercury. This process resulted in the release of $108,000-212,000 \mathrm{~kg}(239,000-470,000 \mathrm{lb})$ of mercury into East Fork Poplar Creek (EFPC) between 1953 and 1983. Although the primary mercury discharges from the $Y-12$ Plant were eliminated in 1963, mercury continues to be released in EFPC from the Y-12 Plant and secondary sources (e.g., building drain systems, sewers, and connecting lines). The current release is between 10 to $15 \mathrm{~g} /$ day, down from $100 \mathrm{~g} /$ day in 1985. Releases are regulated under the Clean Water Act NPDES permit for the Y-12 Plant. Portions of the sewers were relined in 1986-87 to reduce mercury contamination. Efforts continue to further reduce mercury discharges [e.g., D\&D, Reduction of Mercury in Plant Effluents (RMPE), and remediation of mercury-use areas]. Overall, the pace of mercury activities at the Y-12 Plant is ahead of the compliance schedules in the NPDES permit, and new opportunities 
are being recognized for achieving additional mercury reductions. These opportunities were not felt to be achievable several years ago.

In addition to the creek and floodplain, the Sewer Line Beltway was constructed by the city of Oak Ridge during 1982 and 1983 and contains over 10 miles of sanitary interceptor sewers and force mains. In certain instances, EFPC floodplain soils were used to provide topsoil. No records were kept to document the backfill procedures and locations.

The cleanup objective for the site is to prevent current and future user exposure to mercury-contaminated soils. With significant community input and participation, a proposed mercury action level of $180 \mathrm{ppm}$ was raised to $400 \mathrm{ppm}$, and excavation of floodplain soils above this action limit received regulatory approval in a ROD in August 1995. The excavated soils will be disposed of in a permitted landfill at the Y-12 Plant, and the excavated areas will be backfilled with clean soil.

\section{Accomplishments}

The Lower East Fork Poplar Creek Remedial Design Work Plan, DOE/OR/01-1395\&D2, was issued for review and comment in January 1996. In support of an accelerated approval, comments were received from TDEC in November 1995 and approval from EPA in February 1996.

\section{Concerns}

Concern: Access agreements with property owners need to be renewed. Impact: If continued, this delay may impact the ability to satisfy the requirement of beginning construction 15 months from the date of ROD approval. Action: Real estate access assessments are continuing with private property owners affected by the LEFPC remediation.

\section{Scheduled Activities for Next Quarter}

Continue renewal of access agreements with property owners.

Phase I of the remediation will begin.

The Phase II Remedial Design Report will be issued.

\subsubsection{Lower Watts Bar Reservoir}

\section{Area of Concern}

\section{Lower Watts Bar Reservoir}

\section{Description}

The Lower Watts Bar Reservoir is located on the Tennessee River just below its confluence with Clinch River and is the first impoundment downstream of ORR. This OU consists of the lower portion of the reservoir that extends from Tennessee River Kilometer 913.1 (River Mile 567.5; mouth of the Clinch River at Kingston) to Watts Bar Dam, Tennessee River Kilometer 853.6 (River Mile 530.5). The source of ORR contaminants in this OU is the Clinch River. Because the dam was completed prior to the start of operations at ORR and also because the reservoir acts as an efficient trap for sediments and any associated particle-reactive contaminants, much of these contaminants have accumulated in the bottom of Watts Bar Reservoir over the years. Contaminants released from 
the reservation into these water systems include a variety of radionuclides, metals, and organic compounds, with PCBs and cesium being of particular concern. The PCBs are identified as a concern through fish ingestion, and the screening-level human health risk assessments indicate that cesium is a risk only if deep-channel sediments are dredged and the spoils placed on land and used for agriculture. TDEC has issued a fish consumption advisory for Watts Bar Reservoir, and the Tennessee Valley Authority has placed a ban on dredging. With these two administrative controls and a Memorandum of Agreement in place between DOE and the Tennessee Valley Authority, a ROD for this site was approved in September 1995. The ROD adopts the Tennessee Valley Authority ban on dredging and the TDEC fish consumption advisory and requires a continued monitoring plan for the site.

The RA Work Plan for Lower Watts Bar Reservoir, DOE/OR/02-1376\&D2, was issued and approved. This plan is essentially a monitoring and assessment plan that details the sampling media, analyses, sampling frequency, and sample locations that will be evaluated to assess if conditions change, which may warrant more rigorous RAs.

\title{
Accomplishments
}

Monitoring according to the ROD was initiated.

\section{Concerns}

None.

\section{Scheduled Activities for Next Quarter}

Monitoring according to the ROD will continue.

A detailed summary of monitoring data will be prepared for inclusion in the ORR Remediation Effectiveness Report.

\subsection{CHARACTERIZATION AREA STATUS}

Remedial Investigation/Feasibility Studies (RI/FSs) are required by Section XI of the FFA to be conducted at AOCs where additional information is required to determine the need for CERCLA remediation. The CA category of Appendix $C$ of the FFA includes AOCs where additional CERCLA actions (e.g., RI/FS activities, non-time-critical removal actions, etc.) have been deemed appropriate.

\subsubsection{Oak Ridge K-25 Site CA Status}

\subsubsection{K-1070-A Burial Ground Focused RI/FS}

\section{Area of Concern}

\author{
K-1070-A Old Contaminated Burial Ground
}

\section{Description}

K-1070-A Old Contaminated Burial Ground, northwest of Building K-33, was used for the disposal of several types of material from the 1940 s to 1976 . The burial ground contains 
approximately $35,575 \mathrm{ft}^{3}$ of uranium-contaminated material and $2430 \mathrm{ft}^{3}$ of thorium-contaminated material. Other material includes $\mathrm{UF}_{6}$ cylinders, beryllium chips, boron, radioactive $\mathrm{NaF}$, oil, rags, etc. Prior to FY 1996 the project has consisted of a field investigation to determine the nature and extent of groundwater contamination. The results have shown that the burial ground site is atop a highly developed karstic system. Discovery of the karst system has necessitated a re-evaluation of the assumptions and site conceptual model on which the project was originally based. Work scheduled for FY 1996 has been developed to test the new assumptions and conceptual model.

\section{Accomplishments}

Background studies for the K-1070-A Contaminated Burial Ground Groundwater tracer test were completed. The injection of dyes and tracers was completed the week of January 15, 1996, as part of the test.

Addenda to the Focused Sampling and Analysis Plan and Health and Safety Plan were prepared and reviewed to support additional site characterization activities.

Additional site characterization activities were initiated on February 26, 1996. These activities include surface and subsurface soil sampling, infiltration studies, and trench leachate sampling.

\section{Concerns}

None.

\section{Scheduled Activities for Next Quarter}

Complete dye tracer study and site characterization field activities.

Begin preparation of focused RI \& FS reports.

\subsubsection{K-1070-C/D RI/FS}

\section{Area of Concern}

K-1070-C/D Classified Burial Ground (includes K-1070 and K-1071 Concrete Pads; K-1070 Pits; and K-1070 D1, D2, and D3 Storage Dikes)

\section{Description}

The K-1070 area consists of the K-1070-C/D Classified Burial Ground, located on a hill at the eastern edge of the K-25 Site. The burial ground is composed of several disposal areas: large trenches, small pits, three earthen dike areas, a land farm, and a concrete pad. Both low-level radioactive and nonradioactive, nonhazardous waste materials and equipment were buried in the large trenches. The small pits were used to empty drums of hazardous waste. The dikes, which received RCRA closure approval from the state of Tennessee, were used for surface storage of drummed wastes. The land farm is a road onto which potentially contaminated oils were sprayed for dust suppression. The concrete pad was used for compaction of metal drums before burial. Contaminants of concern at the burial ground are volatile and semivolatile organics, uranium-contaminated scrap metal, uranium compounds, lead, and other metals. An interim corrective action was initiated in January 1994 for the SW 31 Leachate Seep, which is located immediately west of the site and has been likely contaminated by the burial ground. 
The results of a recently completed RI/FS have shown the need for RA at two distinct sites in the K-1070-C/D Classified Burial Ground. The two units are the K-1071 concrete pad and the $\mathrm{K}-1070-\mathrm{G}$ pit. Remediation of these two units will be initiated upon approval of the scheduled ROD for the K-1070-C/D Burial Ground.

\section{Accomplishments}

The K-1070-OU Proposed Plan was issued to regulators for review on January 16, 1996.

TDEC comments were received on the Proposed Plan on March 6, 1996.

Preparation was begun on the Statement of Work for the G-pit recharacterization.

\section{Concerns}

- None.

\section{Scheduled Activities for Next Quarter}

Address regulatory comments on the Proposed Plan. Begin preparation of the ROD.

Prepare support documentation for task order planning. Initiate work to recharacterize the G-pit to collect predesign information.

\subsubsection{K-1007-P1 Pond Site Assessment}

\section{Area of Concern}

K-1007-P1 Holding Pond

\section{Description}

The K-1007 P1 Pond, formerly known as the K-1007-B Pond, is located outside Portal 2 on the southwestern boundary of the K-25 Site. The K-1007-P1 Pond has historically received discharges from the laboratory complex and from process building storm drains around the K-25 Site. The pond currently receives discharges from five storm drains. Previous sampling activities in the late $1980 \mathrm{~s}$ and the 1990s revealed high levels of PCBs in largemouth bass in the K-1007-P1 Pond and in sediment. If ingested, the levels of PCB in the fish present an unacceptable human health risk. As a result of the elevated levels of PCBs found in the fish, warning signs were placed around the boundary of the pond, and guard patrols were increased. Work scheduled for FY 1996 includes planning and scoping a feasible RA and documentation appropriate for the action.

\section{Accomplishments}

The Engineering Evaluation/Cost Analysis (EE/CA) notification letter and FFA milestone dates for the AM and the Removal Action Work Plan were submitted. These dates will appear in the revised Appendix E of the FFA.

\section{Concerns}

None. 


\section{Scheduled Activities for Next Quarter}

Begin preparation of the EE/CA.

\subsubsection{K-1131/K-1410 Area Demolition and K-725 Beryllium Building Removal (Group 1 K-25 Auxiliary Facilities Assessment)}

Area of Concern

K-1410 Plating Facility, K-1031-A Building, K-725 Beryllium Building, K-724 Storage Building, $\mathrm{K}-1131$

\section{Description}

The two separate projects for (1) K-1131/K-1410 Area Demolition and (2) K-725 Beryllium Building Removal have been combined into one project for management purposes. The five facilities included in these two projects (K-725, K-724, K-1131, K-1410, K-1031) are now the Group I facilities under the K-25 Auxiliary Facilities Assessments. One EE/CA is currently being prepared for these five facilities in accordance with milestones contained on the FFA Appendix E. A brief description of the facilities follows.

$\mathrm{K}-725$ is a small $\left(21,600-\mathrm{ft}^{2}\right)$ building in the powerhouse area for which there are limited access controls. This building, along with the nearby $\mathrm{K}-724$ Warehouse Building $\left(8,600 \mathrm{ft}^{2}\right)$, was originally part of the S-50 thermal diffusion process for enriching uranium. The buildings were later used in the Nuclear Energy Propulsion for Aircraft project. Both facilities were constructed in the mid-1940s and are known to be contaminated with beryllium and radioactivity in excess of release limits. Both the K-724 and K-725 buildings are structurally deteriorated and have leaky roofs.

The K-1031, K-1131, and K-1410 facilities were built in the mid-1940s and are all shutdown facilities located adjacent to Poplar Creek. K-1131 (55,700 $\left.\mathrm{ft}^{2}\right)$ was used to support the gaseous diffusion process UF $_{6}$ production, $\mathrm{HF}$ handling, UF feed vaporization, and depleted UF tails withdrawal). K-1131 contains high levels of radioactive contamination which exceed release limits, and part of its roof has failed, allowing rainwater inflow to the building contents. $K-1410\left(9,000 \mathrm{ft}^{2}\right)$ was originally used for decontaminating equipment with uranium contamination and later for nickel-plating metal parts of uranium enrichment equipment. This facility also contains high levels of radioactive contamination which exceed release limits and is in a deteriorated condition from roof leaks. K-1031 $\left(2,900 \mathrm{ft}^{2}\right)$ was a maintenance and storage facility in support of the decontamination operations in nearby $\mathrm{K}-1410$. This facility contains radioactive contamination which exceeds release limits.

D\&D of these facilities may include demolition to be performed under CERCLA's non-time-critical removal process as established in the May 22, 1995, joint DOE and EPA "Policy on Decommissioning of Department of Energy Facilities under CERCLA." An EE/CA and associated $\mathrm{AM}$ will be prepared as the decision documentation. This task includes conducting the assessments for these auxiliary facilities and preparing decision documentation and any other project documentation pertinent to site preparations for eventual decommissioning. The decommissioning phase will follow the preparation of the decision documents.

\section{Accomplishments}

Preparation of the EE/CA continued. 
Concerns

None.

Scheduled Activities for Next Quarter

Continue preparation of the EE/CA.

\subsubsection{Oak Ridge National Laboratory CA Status}

\subsubsection{White Oak Creek Watershed}

\section{Area of Concern}

All AOCs listed in Appendix C for the Melton Valley area of ORNL

\section{Description}

A project has been initiated to prepare an RI/FS for the Melton Valley portion of the White Oak Creek (WOC) watershed at ORNL. This watershed encompasses essentially all of the contaminated areas within the Melton Valley area of ORNL. The project will use existing data, possibly supplemented by a small amount of new data, to prepare an RI/FS for ORNL that can be used by the decision makers and stakeholders to select a preferred alternative for the remediation of ORNL. Selection of the preferred alternative will establish the remediation goals for ORNL and identify the sequence of actions necessary to reach the goal.

\section{Accomplishments}

Work on the FS continued; eight site-wide alternatives were developed, each addressing all sources and contaminated media associated with the ORNL historic activities.

A data quality objectives workshop was held in February between DOE, EPA, TDEC, and other project participants. Data summary sets on the, WOC basin were produced for the workshop by compiling existing data on the various WAGs in the basin. The conceptual model for ORNL was presented and will be incorporated as a supporting document to the RI report. The results of the meeting were that little data are believed to be needed to complete the RI. Specific sampling locations were identified at the data quality objectives workshop for the data needed.

\section{Concerns}

None.

\section{Scheduled Activities for Next Quarter}

Continue preparation of the FS.

Initiate preparation of the summary level $\mathrm{RI}$ report, which will include the baseline risk assessment conceptual model and the fate and transport of contaminants. 


\subsubsection{ORNL WAG 1 Gunite and Associated Tanks}

Area of Concern

Inactive LLLW Collection/Storage Tanks W-1, W-2, W-3, W-4, W-5, W-6, W-7, W-8, W-9, W-10, W-11, W-13, W-14, W-15, W-1A, and TH-4

\section{Description}

This area consists of the underground steel and Gunite tanks associated with two tank farms located in the center of the ORNL main plant area. The GAAT area includes the tanks located in the North Tank Farm and the South Tank Farm as well as Tanks TH-4 and W-11. This area includes the large Gunite tanks installed in 1943 to store liquid wastes and subsequently used as the main holding tanks for the LLLW system at ORNL. A number of steel tanks associated with the North Tank Farm are also included in this area. The strategy of this grouping is to allow those tanks that are located together to be remediated as a group and also to complete the remediation of all of the Gunite tanks at ORNL.

The GAAT area is commonly referenced as three separate tank groups:

- Group 1 tanks: W-1, W-1a, W-2, W-11, W-13, W-14, and W-15;

- Group 2 tanks: W-3, W-4, W-5, and TH-4; and

- Group 3 tanks: W-6, W-7, W-8, W-9, and W-10.

The GAAT project is currently conducting treatability studies to determine the most effective way to remediate sludges remaining in the tanks. The studies include testing methods for removing and/or treating sludges from the tanks. The accomplishments and concerns identified herein are common to all of the three tank groups.

\section{Accomplishments}

The Pathway Transport Modeling Report (DOE/OR/02-1454\&D1) was submitted to TDEC and EPA.

Construction activities were completed for (1) the installation of nine tank access risers, foundations, and the steel platform which will be used to support waste removal and treatment equipment during the treatability testing in tanks W-3 and W-4; (2) utilities and the high-efficiency particulate air (filter) exhaust systems for Tanks W-3 and W-4; (3) decontamination spray rings, tank/riser interface containment, hose management, and waste transfer systems; and (4) design of the modified light-duty utility arm.

Agreement has been reached for DOE Technology Development to supply a robotic vehicle for use in the Treatability Study waste retrieval testing activities.

Preparation of the FS for Group 2 Tanks (W-3, W-4, W-5, W-6 and TH-4) began. in March.

The final design review for the waste dislodging and conveyance system was conducted 


\section{Concerns}

None.

\section{Scheduled Activities for Next Quarter}

The RI Addendum Report will be issued. Phase II sampling results will be presented in this document.

The final design package for the waste dislodging and conveyance system will be issued in April.

The results of the treatability study and the proposed scope of work for the first FS will be discussed at the April FFA Project Managers' Meeting.

The results of the treatability study and the proposed scope of work for the first FS will be discussed at the public meeting scheduled for May.

The following construction-related activities will continue: (1) installation of utility and high-efficiency particulate air (filter) exhaust systems, (2) modifications to the Cold Test Facility, (3) cold testing of the spray ring decontamination system, (4) fabrication of the hose management and waste transfer systems, and (5) fabrication of the confined sluicing end effector.

The following documents will be issued:

- Results of the 1995 Characterization of Gunite and Associated Tanks

- Leaching Studies and Miscellaneous Data for Gunite and Associated Tanks

- Evaluation of Phase I and Phase II Sampling and Analysis Data for the Gunite and Associated Tanks

- Treatability Study Operational Testing Program Implementation Plan Gunite and Associated Tanks

- Structural Analysis of Underground Gunite Storage Tanks

- Preliminary Evaluation of Liquid Integrity Monitoring Methods for the Gunite and Associated Tanks

- Design Assessment for the Melton Valley Storage Tanks Capacity Increase

\subsubsection{ORNL WAG 1 Surface Impoundments}

Area of Concern

Waste Holding Basin 3513, Equalization Basin 3524, Process Waste Ponds 3539 and 3540

\section{Description}

The WAG 1 Surface Impoundments consists of four surface impoundments located in the south-central portion of the ORNL main plant area. A brief description of each of the four impoundments follows. 
Basin 3513. This unlined impoundment was constructed in 1944 in natural clays to serve as a settling basin for untreated waste waters before their discharge into the adjacent WOC. This impoundment is no longer used, but water levels are maintained to provide shielding for radioactive sediments.

Basin 3524. This unlined impoundment was constructed in 1943 in natural clays to serve as an intermediate storage, collection, and mixing basin for the process waste treatment system located in Building 3544. Currently, this impoundment is used only as surge capacity for storm water during peak storm events.

Ponds 3539 and 3540. These clay-lined impoundments were constructed in 1964 to serve as surge capacity for process waste streams, primarily from the Building 4500 complex. Currently the ponds are used as surge capacity for storm water during peak storm events.

Impoundments 3524,3539 , and 3540 will be taken out of service completely when the new surge tank is brought on line in early mid-1996.

\section{Accomplishments}

The Proposed Plan for the Surface Impoundments Operable Unit WAG 1 (DOE/OR/02-1427\&D1) was submitted to EPA and TDEC for review and comment. The preferred alternative identified for remediation of the contaminated sediments was consolidation with simple dewatering in an on-site cell built essentially to RCRA landfill performance standards. Comments have been received from the regulators and the $\mathrm{D} 2$ version is being prepared.

A contract has been awarded for the engineering support study. Field work began in March.

Preparation of the ROD has begun.

\section{Concerns}

None.

\section{Scheduled Activities for Next Quarter}

Prepare D2 version of the Proposed Plan.

Continue preparation of the ROD.

Begin the prequalification process for remedial contractors.

Schedule and conduct the public meeting for the Proposed Plan.

\subsubsection{ORNL WAG 1 Groundwater}

\section{Area of Concern}

The AOCs for WAG 1 coincide with the body of shallow groundwater beneath the main plant area within Bethel Valley. 


\section{Description}

The WAG 1 groundwater activities focus on shallow groundwater that discharges to surface streams within WAG 1 . The potential exists for contaminant migration from various sources within WAG 1 through both shallow and deeper groundwater to off-WAG receptors. This project is entering into a period of monitoring and characterization to identify contaminant sources and their migration pathways, with the objective of identifying potential locations for early actions.

\section{Accomplishments}

Drive point installation to continue the attempt to identify a local contaminant source for the Core Hole 8 contaminated groundwater plume was completed.

Semiannual sampling was initiated.

Interchange of the file format data package was completed for the Fourth Annual Environmental Restoration Monitoring and Assessment Report (FY 1995).

\section{Concerns}

None.

\section{Scheduled Activities for Next Quarter}

Continue drive point installation to continue the attempt to identify a local contaminant source for the Core Hole 8 contaminated groundwater plume.

Continue monthly and continuous water level monitoring.

Continue semiannual monitoring.

\subsubsection{ORNL Surface Water Program}

Area of Concern

All AOCs at ORNL except WAGs 11 and 13

\section{Description}

The Surface Water Program proposes to conduct a series of monitoring, characterization, and data assessment tasks to meet three primary objectives:

- determine the effectiveness of ongoing response actions in reducing contaminant releases into and from the WOC watershed;

- provide information to develop baseline contaminant conditions in the WOC, Raccoon Creek, and Bearden Creek watersheds to be used primarily as part of the new WOC watershed RI/FS initiative; and

- provide information to help evaluate future response actions in the WOC watershed. 
The activities will focus primarily on the WOC watershed, which is the surface water drainage for the main plant area and major WAGs at ORNL. Some characterization activities will take place in Raccoon Creek and Bearden Creek to baseline the contaminant release conditions in these two drainages.

Much of the focus of the program will be on evaluating the effectiveness of recent and planned response actions, including WAG 5 Seeps $C$ and D, Core Hole 8 plume collection system, and WAG 4 seeps. The general approach for evaluating WAG 5 seeps and Core Hole 8 will be to determine the effectiveness of the treatment unit itself and the effectiveness of the response action on reducing contamination in the watershed by sampling at major weirs and White Oak Dam.

\section{Accomplishments}

Sampling and analysis of surface water was initiated per the FY 1996 Surface Water Project Plan.

\section{Concerns}

None.

\section{Scheduled Activities for Next Quarter}

Continue sampling and analysis of surface water and assessment of surface water data.

A detailed operational summary on the recovery and treatment systems sampled as a result of the AMs (WAG 4 Seeps, WAG 5 Seeps, and Core Hole 8) will be prepared for inclusion in the ORR Remediation Effectiveness Report.

\subsubsection{ORNL WAG 2 (White Oak Creek Embayment and Tributaries)}

\section{Area of Concern}

WOC and Tributaries, White Oak Lake and Embayment

\section{Description}

ORNL WAG 2 includes two sites. The first site consists of the area encompassed by the stream channels of WOC and Melton Branch; the second site includes White Oak Lake, White Oak Dam, and the WOC Embayment prior to confluence with Clinch River. WOC/White Oak Lake and its tributaries represent the major drainage system for ORNL and the surrounding facilities.

WOC and its tributaries are located in Melton and Bethel valleys. WOC flows into Clinch River at River Mile 20.8, about 1.5 miles north of the junction of Interstate 40 and State Highway 95 . White Oak Lake is located upstream of White Oak Dam and just south of the ORNL main complex. White Oak Creek Embayment encompasses the area downstream of White Oak Dam to the confluence of WOC with Clinch River ( 0.6 mile). White Oak Lake is a surface impoundment that serves as a final settling basin for particle-reactive contaminants from ORNL operations and waste storage areas. Contaminants of concern identified to date are ${ }^{90} \mathrm{Sr} ;{ }^{137} \mathrm{Cs} ;{ }^{60} \mathrm{Co}$; thorium; uranium; transuranics; metals (mercury, zinc, and chromium); and some organic compounds (including PCBs) located primarily in bottom sediments. 
Site-wide surface water assessment activities are conducted as the ORNL Area Surface Water Program. Groundwater assessment activities are conducted as the ORNL Area Groundwater Program. By drawing together data collection and assessment activities, the surface water and groundwater programs will provide ER the management tools needed for timely decision making to conduct RAs with maximum efficiency and cost effectiveness.

An RI was initiated on WAG 2. Sample collection is completed and laboratory analysis data are being validated. The results of the WAG 2 RI will not be published in an RI report. Instead, the data will be published in five separate information assessment reports to be completed and issued in FY 1996. The task areas covered by the individual reports include seep and tributary assessment, human health risk, ecological risk assessment, and sediment transport modeling in WAG 2.

\section{Accomplishments}

The first two information assessment reports were completed: WAG 2 Phase I RI Report: Tributary Data Assessment, ORNL/ER-362; and WAG 2 Phase I RI Report, Seep Task Data Report: Contaminant Source Area Assessment, ORNL/ER-363.

Work continued on the preparation of the three remaining information assessment report.

\section{Concerns}

None.

\section{Scheduled Activities for Next Quarter}

Task team efforts within the WAG $2 \mathrm{RI}$ are focused on the development of the three remaining information assessment reports to be completed and issued in FY 1996. Work activities underway to produce these reports include analytical laboratory analysis, data validation, data verification, summary data compilation, technical analysis, interpretation, evaluation, and report preparation.

\subsubsection{ORNL WAG 4 Seeps Collection and Treatment}

\section{Area of Concern}

Solid Waste Storage Area 4

\section{Description}

WAG 4 is located in Melton Valley, immediately south of the main plant area through a gap in Haw Ridge. This WAG consists of three areas: (1) Solid Waste Storage Area 4, which is a shallow land burial ground containing radioactive and hazardous wastes; (2) two pilot-scale LLLW waste seepage trenches; and (3) an underground pipeline used for transferring liquid radioactive wastes from the ORNL main complex to waste pits and trenches in WAG 7. Site investigations conducted during FY 1994 and FY 1995 have identified four isolated trench areas which are believed to contribute about $70 \%$ of the ${ }^{90} \mathrm{Sr}$ exiting Solid Waste Storage Area 4. An EE/CA and an AM have been prepared for this non-time-critical removal action; these documents identify the use of low-pressure grouting of the four trenches as the preferred alternative.

The objective of the low-pressure grouting is to reduce the hydraulic conductivity of the source areas, thereby isolating the ${ }^{90} \mathrm{Sr}$ source material from the groundwater flow system. Site preparation 
activities comprising the preparation of a work area and relocation of an overhead power line are planned.

Accomplishments

Comments were received from the regulators, and the D2 AM was issued on February 15, 1996.

Site preparation activities commenced on March 4, 1996.

Grouting specifications were approved on March 14, 1996.

\section{Concerns}

None.

\section{Scheduled Activities for Next Quarter}

Submit the Removal Action Work Plan to the regulators in June.

Commence grouting operations in July (scheduled for completion by October 1996).

\subsubsection{ORNL WAG 5 OHF Tank Sludge Removal}

Area of Concern

Old Hydrofracture Facility (OHF) LLLW Tanks T-1, T-2, T-3, T-4, and T-9

\section{Description}

OHF, located in WAG 5, was used from 1964 to 1979 for permanent disposal of liquid radioactive waste in shale formations at depths between 780 and $950 \mathrm{ft}$. More than 2 million gal of LLLW and grout mixture containing several hundred thousand curies of beta-gamma radionuclides - primarily ${ }^{137} \mathrm{Cs},{ }^{90} \mathrm{Sr}$, and ${ }^{60} \mathrm{Co}$, with lesser amounts of ${ }^{233} \mathrm{U},{ }^{23 \times} \mathrm{Pu},{ }^{244} \mathrm{Cm}$, and ${ }^{241} \mathrm{Am}-$ were injected. The OHF facility contains five carbon-steel, underground storage tanks that ranged in volume from 13,000 to 25,000 gal. These tanks were used for storage of LLLW before mixing with grout for injection. During OHF operations, radioactive sludges accumulated in the tanks as particles settled out of the liquid in the tanks. A non-time-critical removal action was initiated in 1995 to remove the sludges from the five LLLW tanks at the OHF area.

\section{Accomplishments}

Sampling of both supernatant and sludge in the OHF tanks was completed.

The EE/CA (DOE/OR/02-1450\&D1) was submitted to the regulators for review and comment ahead of schedule. The EE/CA identifies the sluicing and pumping alternative as the preferred remedy.

The draft Final Site Characterization Summary Report was completed. 
Internal video inspection of the OHF tanks was completed. The results of the inspection indicated that the three nonrubber-lined tanks have 50\% nonuniform corrosion (pitting and scaling). The two rubber-lined tanks were in good condition.

\section{Concerns}

None.

\section{Scheduled Activities for Next Quarter}

Respond to regulatory comments on the EE/CA.

Perform sludge sampling and a visual inspection of all OHF tanks to collect data to assist in the engineering design of the anticipated action to remove the sludges.

Evaluate data and information collected during inspection activities.

Begin preparation of the AM.

\subsubsection{ORNL Area-Wide Groundwater Program}

\section{Area of Concern}

The AOC is defined as the area bounded on the north by Pine Ridge, on the south by Copper Ridge, on the west by Clinch River, and on the east by Bearden Creek.

\section{Description}

Groundwater flow paths and restoration activities are not constrained by WAG boundaries. Therefore, groundwater activities associated with individual contaminant/WAG source OUs have been integrated over a larger geographic area. The area-wide groundwater OU underlying Melton and Bethel valleys has been established and will be the focus of multi-year, long-term characterization and monitoring activities. Focused RAs will be implemented as required.

\section{Accomplishments}

Water level information was collected from existing groundwater monitoring wells, and materials for upgrading of existing wells were procured. Information collected under this effort will be used as input to the conceptual groundwater/contaminant flow path model.

Groundwater sampling and analysis activities were initiated under the groundwater characterization and modeling task.

Geophysical surveys were implemented under the well installation and upgrade task.

\section{Concerns}

None. 


\section{Scheduled Activities for Next Quarter}

Continue groundwater sampling and analysis activities under the groundwater characterization and modeling task.

Continue geophysical surveys under the well installation and upgrade task.

\subsubsection{ORNL WAG 7 Pit 1 In Situ Vitrification}

\section{Area of Concern}

Pit 1

\section{Description}

In situ vitrification (ISV) has been selected as the baseline closure technology for several pits and trenches at WAG 7. The ISV activity will continue in FY 1996 with a field-scale demonstration of two adjacent melts in Pit 1 whereby contaminated soil particles will be melted into a glass matrix. A treatability study will provide necessary information regarding the design, implementation, and performance of ISV for Pit 1 and other sites with known similar soil contamination. Pit 1 was selected for the demonstration because of its limited size $\left(30,000 \mathrm{ft}^{3}\right)$ and radionuclide inventory (87 Ci of mixed fission products). The major objectives of ISV-related work in FY 1996 include completing design and fabrication of the ISV off-gas filter system and collection hood; completing the Pit 1 site characterization; completing all environmental, safety, and health documents; and obtaining approval for performing the treatability study. The technical objectives to be accomplished for ISV-related work are the following:

- attaining the required depth for incorporating source contamination,

- demonstrating field procedures for overlapping at least two melts,

- demonstrating off-gas handling techniques for any volatilized ${ }^{137} \mathrm{Cs}$,

- demonstrating adequate site characterization techniques, and

- promoting stakeholder acceptance.

Recent findings have indicated that some radionuclides can be readily volatilized from soil during thermal treatments. In some cases, volatilization of the radionuclide is preferable to retention in an ISV melt. The thermal soil decomposition studies initiated in FY 1994 for ${ }^{137} \mathrm{Cs},{ }^{90} \mathrm{Sr}$, ${ }^{99} \mathrm{Tc}$, and radioactive uranium contaminants will be summarized in a technical report in FY 1996. These data will constitute a valuable adjunct in the evaluation of ISV as a closure technology.

\section{Accomplishments}

Repairs to the off-gas structural system, reassembly of the off-gas hood, and test and check of all ISV system components were completed.

An equipment operational acceptance test was initiated.

\section{Concerns}

None. 


\section{Scheduled Activities for Next Quarter}

Initiate and complete vitrification of Pit 1.

\subsubsection{MSRE Uranium Deposit Removal Non-Time-Critical Removal Action}

\section{Area of Concern}

MSRE Reactor Building [Main Reactor, Reactor Cells, Radiator Stack, Blower House, and Vent House (7503)]

\section{Description}

MSRE is located in Building 7503 in WAG 8, which is situated in Melton Valley. It was part of the Atomic Energy Commission's Molten Salt Reactor Program, which was built to investigate the concept for central power station applications. The reactor first went critical on June 1, 1965, and was shut down on December 12, 1969. A surveillance and maintenance program was initiated and continues on the shutdown facility. Elevated radiation readings detected in June 1994 indicated migration of radioactive contamination outside the fuel drain tank cells. Subsequent analyses and tests showed evidence of uranium hexafluoride $\left(\mathrm{UF}_{6}\right)$ in the Auxiliary Charcoal Bed, located in the Charcoal Bed Cell.

This non-time-critical response action comprises the removal of potentially reactive $\mathrm{UF}_{6}$ from the Auxiliary Charcoal Bed. Once the gases are removed from the off-gas system and conditions around the Auxiliary Charcoal Bed and the and the Charcoal Bed Cell are stabilized, the removal of the fissile uranium can be completed.

\section{Accomplishments}

The EE/CA (DOE/OR/02-1439\&D1) was submitted to the regulators. Comments to the D1 document have been received.

Fabrication is about $80 \%$ complete for the Charcoal Bed Cell mock-up that will test equipment and systems for the Auxiliary Charcoal Bed uranium deposit removal operations.

\section{Concerns}

None.

\section{Scheduled Activities for Next Quarter}

The D2 version of the EE/CA for the non-time-critical removal action for the charcoal bed cell uranium deposit removal will be provided to EPA, TDEC, and the public for comment.

Preparation of the AM will begin. 


\subsubsection{MSRE Fuel Salt Remedial Action Project}

Area of Concern

MSRE Reactor Building (7503)

\section{Description}

MSRE is located in Building 7503 in WAG 8, which is situated in Melton Valley. It was part of the Atomic Energy Commission's Molten Salt Reactor Program, which was built to investigate the concept for central power station applications. The reactor first went critical on June 1,1965, and was shut down on December 12, 1969. A surveillance and maintenance program was initiated and continues on the shutdown facility. Elevated radiation readings detected in June 1994 indicated migration of radioactive contamination outside the fuel drain tank cells. Subsequent analyses and tests showed evidence of uranium hexafluoride $\left(\mathrm{UF}_{6}\right)$ in the Auxiliary Charcoal Bed, located in the Charcoal Bed Cell.

\section{Accomplishments}

The fuel salt disposition task is fully staffed and organized into five working groups: (1) chemistry and process development; (2) mechanical and robotics; (3) analysis; (4) documentation, including definition of remedial objectives; and (5) risk. Specific tasks and schedules are being established for the working groups. Personnel supporting other areas, such as cost and regulatory compliance, will be assigned tasks when needed. The primary focus is on identifying and evaluating alternatives for waste management and for removal and processing technologies.

Preparation of the FS commenced in January.

\section{Concerns}

None.

\section{Scheduled Activities for Next Quarter}

Continue preparation of the FS.

\subsubsection{Oak Ridge Y-12 Plant CA Status}

\subsubsection{UEFPC CA}

\section{Area of Concern}

The 58 sites are listed in the Appendix $\mathrm{C}$ under the UEFPC CA.

\section{Description}

The UEFPC CA consists of both surface water and groundwater components of the UEFPC watershed and appropriate sources located within that watershed. This complex CA, which contains multiple contaminants, multiple contaminant sources, and commingled plumes, is a point of origin for both off-site surface water and groundwater contamination. The CA is bounded (in general) by the base of Pine Ridge to the north and Chestnut Ridge to the south. The boundary extends westward, 
where it abuts the boundary of the Bear Creek CA, and eastward to the DOE property line. The CA will also address a carbon-tetrachloride-contaminated groundwater plume that extends past the DOE property line and surface water in UEFPC extending to where the scope of LEFPC begins.

Numerous primary sources exist within the CA. Infiltration from the S-3 Area dominates contamination in the western portion of the CA. Contaminated soils in the Salvage Yard, the S-2 Area, and the 81-10 Area are also known contaminant source areas in the CA. There are approximately 58 additional FFA-identified release sites within the boundaries of the CA. Many of these sites are of known low priority as contaminant sources to the environment; however, many may need additional evaluation.

An extensive array of storm drains that mimic the original natural drainage patterns in the UEFPC CA gathers runoff from the main plant area in catch basins located across the plant. In addition, this drainage system, which was once connected to process equipment, discharged untreated waste streams. No untreated waste streams are currently discharged into the storm sewer system, but remnant contamination may be retained in sediments in the drainage system. The storm sewer network contains several miles of drainage pipes and culverts that range up to 108 in. in diameter. UEFPC begins near the middle of the Y-12 Plant and, according to water balances for the plant, is fed primarily from the storm sewer system. Groundwater infiltration into the storm sewer system and groundwater discharge directly into the creek are significant additional sources of UEFPC flow.

Because of the wealth of historical data available for this CA, a streamlined RI/FS approach has been proposed and accepted by the FFA parties. This approach will use historical data to the fullest extent possible to complete the RI/FS, it will focus additional data collection efforts on FS needs, and it will use uncertainty management techniques to bound rather than fill data deficiencies. Because the CA is underlain by an extensive storm sewer system, a subbasin approach will be used to link information from potential source areas (i.e., soil data and inventories) to historical surface water and shallow groundwater data. This approach, together with groundwater contaminant plume maps, will allow large areas of the plant (each subbasin) to be prioritized according to the relative contaminant contributions to surface water and groundwater. The RI Work Plan for this CA (DOE/OR/01-1396\&D1) was issued September 1995 and is the documented road map for the approach described above. Although this document is titled "Work Plan," a Remedial Site Evaluation Report will need to be submitted before the field work decision document to establish the conclusions made on the historical data. Historical data retrieval and analysis are being conducted as outlined in the RI Work Plan. In addition, a comprehensive sump identification and sump information inventory effort is nearing completion. Development of preliminary FS alternatives and a screening of existing technologies has begun.

\section{Accomplishments}

Comments on the RI Work Plan were received from TDEC and EPA.

The D2 version of the RI Work Plan was submitted to TDEC and EPA for approval.

The groundwater radiological characterization began in February and was completed in March. EPA and TDEC cosampled several sites during this effort.

\section{Concerns}

Concern: Despite the tremendous progress made in RMPE, the NPDES permit requires UEFPC to be at state water quality standards for mercury on the last day of the permit. This is unattainable 
with current technology. Impact: Without technology advancements, the NPDES requirements will not be met. Action: An appeal to the NPDES permit has been submitted. The ongoing CERCLA activities for the UEFPC CA will be considered a vehicle to obtain risk-based relief from the NPDES permit requirements. Under the current RI/FS schedule, the UEFPC CA ROD will not be complete by the last day of the permit. The project team is preparing a white paper proposal for submittal to the regulators for agreement to a potential interim action for mercury.

\section{Scheduled Activities for Next Quarter}

Continue analysis of historical data.

Continue screening of technologies and development of preliminary FS alternatives.

\subsubsection{Union Valley}

Area of Concern

The 58 sites are listed in Appendix $\mathrm{C}$ under the UEFPC CA.

\section{Description}

The Union Valley area is located in the UEFPC CA and is located about 0.5 mile east of the Y-12 Plant in the Union Valley Industrial Park. In March 1994, DOE announced that elevated levels of four industrial solvents had been found in wells installed by the U.S. Geological Survey, located about 0.5 mile east of the Y-12 Plant in the Union Valley Industrial Park. Elevated levels of these same solvents, which are known as volatile organic compounds, have also been found in groundwater monitoring wells at the Y-12 Plant. A Remedial Site Evaluation Report (Y/ER-206, Rev. 1) for Union Valley has been issued and summarizes on-site and off-site information associated with this site. This report indicated that no usage of contaminated groundwater is currently occurring in Union Valley. In addition, DOE is pursuing an interim ROD to ensure that contaminated groundwater in Union Valley is not used in the future until the problems in the area can be better investigated. Regulatory comments have been received on the Union Valley report, and a comment resolution document has been prepared. Because the Union Valley report was not an FFA deliverable, a modified document will not be issued.

\section{Accomplishments}

The D1 Interim Proposed Plan for Union Valley (DOE/OR/01-1452\&D1) was submitted on an accelerated schedule (i.e., 10 weeks early).

\section{Scheduled Activities for Next Quarter}

EPA and TDEC comments on the Interim Proposed Plan for Union Valley are due by May 14, 1996. The comments will be incorporated and the D2 version will be issued next quarter. 


\subsubsection{Bear Creek CA}

\section{Area of Concern}

Bear Creek Burial Grounds; Hazardous Chemical Disposal Area Boneyard/Burnyard; Sanitary Landfill 1; Rust Spoil Area; Contaminated Construction Pile; Groundwater, Surface Water, Creek Sediment, and Floodplain Soil; S-3 Ponds and Treatment Facility; Oil Retention Ponds 1 and 2; Oil Land Farm and Soils Contaminant Pad; Disposal Area RA Solids Storage Facility

\section{Description}

The Bear Creek CA comprises the following release sites: the S-3 Ponds; the Oil Land Farm; Sanitary Landfill 1; the Boneyard/Burnyard; the Hazardous Chemical Storage Area; the Bear Creek Burial Grounds (A, B, C, D, E, and J); Oil Retention Ponds 1 and 2; the Rust Spoil Area; the Contaminated Construction Spoil Pile; the Disposal Area RA and Oil Land Farm Soil Storage Facilities; Bear Creek and its associated floodplain soils; and the groundwater in this watershed CA. Many of these units were used until the 1980 s as the primary area of disposal of various types for hazardous and nonhazardous wastes generated at the Y-12 Plant. Many of these units were RCRA closed (with waste in place). TDEC issued the final RCRA postclosure permit for the Bear Creek hydrogeologic regime in September 1995.

Groundwater, surface water, floodplain soils, and source units are being evaluated as a single entity (i.e., watershed) to ensure that (1) a consistent approach to remediation is implemented across the valley and (2) RAs at specific sites are prioritized to achieve the greatest risk reduction. The boundaries of this CA extends west from a topographic high near the west end of the Y-12 Plant to the point where Bear Creek exits the valley near State Highway 95.

For this CA in total, field activities for surface water and source term units were completed in March 1995, and floodplain soil sampling was completed in June 1995. Additional groundwater sampling for radionuclide analysis to support the human health risk assessment was completed in August 1995. A data quality assessment report in support of the Bear Creek RI Report was completed. The purpose of this report is to provide an evaluation of the quality assurance and quality control results for the Bear Creek data set. Over 75,000 soil, sediment, groundwater, and surface water analyses were accumulated for use in the Bear Creek RI report. The assessment report indicates that less than $1 \%$ of these analyses are unacceptable for use because of data quality problems. In addition, a work plan for Comprehensive Elemental Analysis of Selected Waters and Soils from Bear Creek Valley has been prepared. This document was prepared to identify the potential presence of classified contaminants in this CA. The results of the sampling and analysis will be incorporated into the OU assessment for Bear Creek. Preparation of the RI and FS reports for this characterization continue.

\section{Accomplishments}

Preparation of the RI report continued.

An in situ surface water treatment demonstration is being planned. The demonstration will be conducted in three phases beginning in FY 1996. Iron filings, sorptive media, wetlands, and phytoremediation technologies are planned to be evaluated. The demonstration will be used to evaluate the cost effectiveness and technical feasibility of passive treatment of contaminated surface water. 
A technical evaluation has been conducted looking at the injection of a chemical solution into the acidic S-3 groundwater plume to reduce uranium migration toward Bear Creek and its tributaries. In addition, predictive analyses of dense, nonaqueous-phase liquid plumes and comparative analyses of on-site versus off-site disposal have been conducted. These efforts, along with preliminary design efforts for water treatment, will support the alternative development and technology screening in the FS process.

\section{Concerns}

None.

\section{Scheduled Activities for Next Quarter}

The in situ grouting demonstration report will be released.

Continue work on preparation of the RI and FS reports. The detailed and comparative analysis of the FS alternatives should be complete and the FS document should be in development.

\subsubsection{Building 9201-4}

\section{Area of Concern}

Building 9201-4

\section{Description}

Building 9201-4 is part of the Mercury-Use Area AOC and is the only official component of the $D \& D$ program located at the $Y-12$ Plant. Numerous asbestos and hazard abatement activities have already been realized in this D\&D project and will continue in FY 1996.

\section{Accomplishments}

Efforts to reduce mercury vapor levels in Building 9201-4 have been very successful. The efforts have been focused on the tray rooms in the building as a maintenance activity under the Y-12 Surveillance and Maintenance Program. The objectives of this cleanup were twofold: (1) to reduce the personal protective equipment needed for personnel in the building, thereby reducing risk and surveillance and maintenance costs and waste, and (2) to maximize the amount of recyclable mercury and other metals. From one tray room subproject, $750 \mathrm{lb}$ of elemental mercury, $100,000 \mathrm{lb}$ of copper, and $65,000 \mathrm{lb}$ of carbon steel have been recovered, with a corresponding $150 \mathrm{lb}$ of waste. Monitoring of mercury vapor in Building $9201-4$ has shown significant improvements in air quality, well below the Occupational Safety and Health Act threshold limit value.

\section{Concerns}

None.

\section{Scheduled Activities for Next Quarter}

Continue cleanup of tray rooms. 


\subsubsection{Bear Creek OU 2}

Bear Creek OU 2 is still identified as an OU under previous and now incorrect nomenclature. This title is still used here for clarity and because a completed decision document is imminent for this site.

\section{Area of Concern}

Spoil Area 1, SY-200 Yard

\section{Description}

Spoil Area 1 is located near the southwest end of the Y-12 Plant, bounded by Old Bear Creek Road and West Patrol Road. Spoil Area 1 was used for the disposal of approximately 100,000 $\mathrm{yd}^{3}$ of nonhazardous, nonradiologically contaminated construction debris. Although plant controls eliminated the disposal of hazardous and radioactive wastes, past plant practices indicate that some of the construction material may have been contaminated with trace amounts of asbestos, mercury, beryllium, thorium, and uranium.

The SY-200 Yard was a 200 - by 300 -ft aboveground storage area located adjacent to Old Bear Creek Road. Materials from several Y-12 Plant and ORNL divisions included PCB transformers, lead shielding plates, and radioactively contaminated materials.

Both sites have clean soil (clay cap) placed on top of the original debris or contaminated soils. Because of the lack of exposure pathways and the lack of groundwater contamination from these sites, a Proposed Plan has been prepared and approved, and a ROD document is in preparation. The preferred alternative includes maintenance of the existing caps.

\section{Accomplishments}

Continued preparation of the D1 ROD.

\section{Concerns}

None.

\section{Scheduled Activities for Next Quarter}

The D1 ROD will be transmitted on or before the milestone date of April 14, 1996. 


\subsubsection{Other Oak Ridge Reservation Areas CA Status}

\subsubsection{Clinch River/Poplar Creek}

Area of Concern

Clinch River/Poplar Creek

\section{Description}

This release site includes Poplar Creek, Melton Hill Reservoir, and Clinch River from Melton Hill Dam to Kingston and focuses on portions that may have been adversely affected by contaminants released from ORR from the mid-1940s to the present. Melton Hill Reservoir and Clinch River downstream from Melton Hill Dam form the southern and eastern boundaries of the ORR. Poplar Creek receives inflow from EFPC, drains the K-25 Site, and then enters Clinch River. Clinch River enters the Tennessee river system of multipurpose impoundments near Kingston, Tennessee, $34 \mathrm{~km}$ downstream from the Oak Ridge complex.

The contaminants released from ORR originate from research, industrial, and waste disposal activities conducted at ORNL, the Y-12 Plant, and the K-25 Site. The contaminants released from these facilities include a variety of radionuclides, metals, and organic compounds. Some liquid wastes were discharged to streams on the ORR, which drain into Clinch River; however, much of the water-borne contamination is derived from seepage into the shallow groundwater from old waste-storage pits and trenches. The contaminants of concern in the river/reservoir system were determined by preliminary human-health risk screening using a variety of exposure pathways and nonconservative screening. PCBs were identified as contaminants of concern through fish ingestion. TDEC has a fish consumption advisory in effect for Melton Hill Reservoir, the Clinch River arm of Watts Bar Reservoir, and other area reservoirs. Poplar Creek is posted by TDEC, advising against fish consumption and water contact because of mercury, metals, and organic chemical contamination. Arsenic, chromium, mercury, selenium, zinc, ${ }^{137} \mathrm{Cs}$, and ${ }^{60} \mathrm{Co}$ are a risk only if deep-channel sediments are dredged and dredge spoil is used for agriculture.

An RI/FS report (DOE/OR/01-1393\&D1) was issued in the fourth quarter of FY 1995.

\section{Accomplishments}

Comments on the D1 RI/FS report were received from EPA.

Continue preparation of the Proposed Plan.

\section{Concerns}

None.

\section{Scheduled Activities for Next Quarter}

Submit the D2 version of the RI/FS report for approval.

Submit the Proposed Plan to the regulators. 


\subsection{REMEDIAL SITE EVALUATION AREA STATUS}

RSEs are required by Section X of the FFA to be conducted at the ORR at all AOCs where CERCLA action may be necessary. In essence, the purpose of an RSE is to determine whether hazardous substances, pollutants, or contaminants have, in fact, been released or that the threat of a release exists and to determine whether CERCLA action, in the form of a RA or a non-time-critical removal action, is needed to mitigate the impacts of the release.

\subsubsection{Oak Ridge K-25 Site RSE Status}

\subsubsection{K-901-A Holding Pond Site Evaluation}

Area of Concern

K-901-A Holding Pond

\section{Description}

The K-901-A Holding Pond received chromated cooling tower water blowdown and a variety of other wastes from cylinders released ballistically over the pond in the late 1950s. Three previous investigations at the K-901-A Holding Pond concluded that there is sediment contamination, unacceptable risk to human health, and potential risk to ecological receptors. The result of the sediment investigation conducted in 1986 indicated elevated levels of contamination existed from chromium, selenium, and zinc. The results of the K-901-A Holding Pond ecological risk assessment, conducted in 1994, indicated that contaminant levels in the fish presented a risk to piscivorous predators. In 1994, a remedial site evaluation was conducted which determined that an unacceptable human health risk existed from the ingestion of PCB-contaminated fish and that a potential risk to ecological receptors, such as herons, mink, and kingfisher, existed (depending on the percentage of diet received from the pond). The site evaluation also confirmed the existence of sediment contamination.

\section{Accomplishments}

The EE/CA notification letter was submitted to the regulators. FFA milestone dates for the AM and the Removal Action Work Plan were also provided.

The Conduct of Operations Improvement Plan was completed.

Comments on the Remedial Site Evaluation Report for the K-901-A Holding Pond were received from EPA and TDEC.

The D2 Remedial Site Evaluation Report was submitted to the regulators.

\section{Concerns}

None.

\section{Scheduled Activities for Next Quarter}

Continue preparation of the EE/CA. 


\subsubsection{K-25 Site Groundwater Remedial Site Evaluation}

Area of Concern

K-25 Site Groundwater

\section{Description}

The K-25 Groundwater Program provides for the assessment and remediation of groundwater at the 1500-acre K-25 Site. The program includes several data-gathering activities that have been designed to characterize the subsurface characteristics and flow regime of the site, provide information on whether or not any contamination may be migrating off site, and establish the relationship of groundwater to surface water. The contaminants in the groundwater at the K-25 Site are radionuclides, principally ${ }^{238} \mathrm{U}$; organic compounds; and heavy metals, including, principally, lead and mercury.

Most of the approximately 220 groundwater monitoring wells across the K-25 Site had not been sampled with any regularity, and very little hydrologic characterization efforts had been completed prior to FY 1994. Additionally, very little source term investigation had been completed; and of those that were completed, groundwater decisions were deferred to a site-wide evaluation of groundwater concerns. For these reasons, several hydrologic characterization activities were planned and initiated to gather sufficient data necessary to support the development of a groundwater Remedial Site Evaluation Report. The report is being developed to support future remediation decisions at the K-25 Site.

\section{Accomplishments}

Preparation of the Remedial Site Evaluation continued.

\section{Concerns}

None.

\section{Scheduled Activities for Next Quarter}

Complete preparation of the Remedial Site Evaluation Report.

\subsubsection{Oak Ridge National Laboratory RSE Status}

\subsubsection{ORNL WAG 10 Hydrofracture Wells Remedial Site Evaluation Area}

\section{Area of Concern}

New Hydrofracture Facility Monitoring Wells

\section{Description}

The objective of this project is to characterize observation and monitoring wells associated with the New Hydrofracture Facility to determine which wells are suitable for recompletion and use as groundwater monitoring wells and which wells require plugging and abandonment in the near term. Results of the characterization will be reported in a Remedial Site Evaluation. 


\section{Accomplishments}

Assessment of radiological and chemical analytical results and geophysical results was initiated.

Preparation began for the report documenting the activities and recommendations for plugging and abandonment or continued monitoring of New Hydrofracture Facility wells.

\section{Concerns}

None.

\section{Scheduled Activities for Next Quarter}

Continue assessment of radiological and chemical analytical results and geophysical results.

Continue development of the report documenting the activities and recommendations for plugging and abandonment or continued monitoring of New Hydrofracture Facility wells.

\subsubsection{ORNL No Further Investigation (NFI) Areas}

\section{Area of Concern}

Ca-45 Tagged Trees

Technetium-95m Contaminated Soil and Plants

Technetium-95m Uptake Studies

Hg-197 Tagged Stream

C-14 Efflux in Yellow Poplar Stand

Hg-203 Tagged Stream

C-14 Allocation in White Pine Trees

Zn-65 Tagged Red Oak Seedlings

C-14 Sucrose Inoculation of Oak and Pine Trees

C-14 Maintenance Respiration Study Site

H-3 Contaminated Trees

\section{Description}

TDEC and DOE-Oak Ridge Operations Office (DOE-ORO) are taking the lead in identifying AOCs on the FFA Appendix $C$ that need further investigation information to determine if the site requires additional CERCLA remediation. Those sites that the parties agree need NFI will be removed from the ER Program.

\section{Accomplishments}

Received TDEC approval of NFI status of AOCs above.

\section{Concerns}

None.

\section{Scheduled Activities for Next Quarter}

Receive FFA project managers' approval of NFI status. 


\subsubsection{Oak Ridge Y-12 Plant RSE Status}

No AOCs have been identified at the Y-12 Plant.

\subsubsection{Other Oak Ridge Reservation Areas RSE Status}

\subsubsection{Freels Bend Area}

\section{Area of Concern}

Low-Dose-Rate Irradiation Facility; Variable-Dose-Rate Irradiation Facility; Animal Burial Sites 1,2 , and 3

\section{Description}

The Freels Bend Area was used to support research conducted at the Oak Ridge Associated Universities' SCF. This 70-acre area is located southwest of the SCF and is bounded on three sides by Clinch River. Control animal herds were maintained on pasture land here with ancillary barns and outbuildings. The research facilities included the Low-Dose-Rate Irradiation Facility and the Variable-Dose-Rate Irradiation Facility. Each of these facilities was used to expose and irradiate test animals that were subsequently observed over a period of time for exposure effects. In addition, there are three reported disposal areas for animal carcasses and miscellaneous wastes: Animal Burial Sites 1, 2, and 3. A Site Investigation was performed at Freels Bend Area in FY 1993. Contaminants of concern included radionuclides, organics, and metals. Radioactive sources were removed from the Low-Dose-Rate Irradiation Facility, and along with the animal burial sites, a decision of NFI was obtained for these four sites. DOE withheld a NFI petition for the Low-Dose-Rate Irradiation Facility until the completion of a scheduled maintenance action at the site. This maintenance action was completed in Spring 1995. In the maintenance action, DOE removed water from 19 cast-iron source containment chambers to prevent leakage to groundwater and filled the source containment chambers with concrete to prevent surface water infiltration. The water removed was sent to the ORNL NonRad Waste Treatment Plant for treatment. DOE determined that by removing the water and preventing future refilling of the chambers, potential sources of environmental contamination were removed from the site and NFI or study is required for the Low-Dose-Rate Irradiation Facility as long as the area remains under $\mathrm{DOE}$ control.

\section{Accomplishments}

Based on review of the sampling results and the Freels Bend Area Maintenance Action Completion Report, TDEC concurred with DOE's decision that no additional RI is required at the Low-Dose-Rate Irradiation Facility. NFI status was approved for this area at the March FFA Project Managers' Meeting. The Freels Bend area will not be reported in future FFA Quarterly Reports.

\section{Concerns}

None.

\section{Scheduled Activities for Next Quarter}

None. 


\subsection{REMOVAL SITE EVALUATION AREA STATUS}

RmSEs are required by Section $\mathrm{X}$ of the FFA to be conducted at the ORR on all newly discovered AOCs and on AOCs which have been listed in the RmSE category of Appendix C of the FFA. The primary objectives of removal site evaluations are to (1) determine the source and nature of a release or threatened release of hazardous substances, pollutants or contaminants; (2) determine the apparent risk posed to human health or the environment from the release; and (3) qualitatively establish the apparent magnitude of the risk.

Removal Site Evaluations are defined in 40 CFR 300.410 and are undertaken by the lead agency for a possible CERCLA response. The Removal Site Evaluation includes a Removal Preliminary Assessment, and if warranted, a Removal Site Inspection.

A Removal Preliminary Assessment is based on available information and may include (1) identification of the source and nature of the release or threat of release, (2) evaluation of the threat to the public health and the magnitude of the threat, and (3) determination if a removal is required. If more information is needed, a Removal Site Inspection may be performed from the perimeter or on site, if necessary. The results of the Removal Site Evaluation must be documented.

\subsubsection{Oak Ridge K-25 Site RmSE Status}

No AOCs have been identified at the K-25 Site.

\subsubsection{Oak Ridge National Laboratory RmSE Status}

\subsubsection{Nuclear Material and Facility Stabilization Program}

\section{Area of Concern}

Alpha Handling Facility (3038)

Alpha Powder Facility (3028)

Fission Product Development Laboratory Inactive Cells (3517)

Isotope Material Laboratory (3038-E)

Radioisotope Development Lab (3047)

Krypton Storage Cubicle (3093)

Krypton-85 Enrichment Facility (3026C)

Metal Segmenting Facility (3026D)

Radioactive Gas Processing Facility (3033)

Radioactive Packaging and Shipping Facility (3038-M)

Radioactive Production Laboratory Annex (3033A)

Radioisotope Production Laboratory C (3030)

Radioisotope Production Laboratory D (3031)

Radioisotope Production Laboratory E (3032)

Radioisotope Production Laboratory H (3118)

Radioisotope Services Building (3034)

Source Development Laboratory (3029)

Storage Pad (3099)

Tritium Target Preparation Facility (7025)

Bulk Shielding Reactor

High Radiation Level Analytical Facility (3019B)

Integrated Process Demonstration Facility (7602) 
Isotope Technology Building (3047)

Tower Shielding Facility

\section{Description}

Building 3026-C-Krypton-85 Enrichment Facility: Building 3026-C is a two-story wooden structure ( $22 \mathrm{ft}$ high) located on Central Avenue to the west of the Isotopes Circle facilities. Ancillary facilities consist of offices, low- and high-level radioactivity laboratories, and a counting room. The facility shares a common wall and utilities with the adjacent Building 3026-D, the Segmenting Hot Cell Facility. The two facilities are operationally independent.

A tritium facility at the northwest corner of Building 3026-C is constructed of reinforced concrete. The small laboratories, counting room, and cell banks are also of reinforced concrete. With the exception of these concrete structures, the partitions and ceilings throughout Building $3026-\mathrm{C}$ are wooden.

The krypton sales program operations in Building 3026-C were discontinued in 1991. Krypton loading equipment in Building 3026-C is still functional and will be used in the final disposal of all residual ${ }^{85} \mathrm{Kr}$ as part of the Isotopes Facilities Deactivation Project-planned activity.

Building 3026-D-Metal Segmenting Facility: Building 3026-D, east of and adjacent to $3026-\mathrm{C}$, is a three-story wooden structure. The principal structure within the building is a two-story, 5 -ft-thick concrete cell block which is divided into two connecting radioactive material handling cells (hot cells) located in a north-south direction. The west face of the cell block is equipped with manipulators and $\mathrm{Zn}-\mathrm{Br}_{2}$-filled viewing windows. To the west of the cell block, located at floor level, is a high-level radioactivity storage facility. This is connected to the south hot cell via a tunnel below the floor for transfer purposes.

The building also houses a Chemical Separation Laboratory in addition to the Segmenting Hot Cells Facility. Historically the Chemical Separations Laboratory has served as a facility for the production and separation of numerous fission products. The Segmenting Hot Cells Facility was originally used to isolate large quantities of fission-produced ${ }^{140} \mathrm{Ba}$ for criticality testing purposes. The cells in the Segmenting Hot Cells Facility were greatly modified since the discontinuance of the earlier ${ }^{140} \mathrm{Ba}$ process to provide facilities for the segmenting, examination, and assembly of irradiated metallurgical specimens. There are no ongoing operations in Building 3026-D other than the storage of irradiated metal specimens.

Building 3028-Alpha Powder Facility: Building 3028 was constructed to separate ${ }^{131} \mathrm{I}$ and later modified to separate ${ }^{133} \mathrm{Xe}$ and other short-lived fission products from uranium-aluminum targets. The building was later expanded to include curium processing cells. It is a steel-frame structure covered by metal siding and is located in the northwest area of Isotopes Circle, directly west of Building 3047.

The building has a four-story central section with one-story cell operating areas on the east and west sides. Cells $1,2,3$, and 4 are manipulator cells with one observation window each. Cells 2 and 3 have back windows with glove ports. Cell 5 is a manipulator cell.

The building was constructed about 1950 as part of the Isotopes Program. It originally housed the ${ }^{131} I$ processing facility (now the Short-Lived Fission Product Cells) and the separation facility (a four-story ion-exchange column) for ${ }^{147} \mathrm{Pm}$. The ${ }^{131} \mathrm{I}$ facility was converted to manipulator cells in the early 1960 s and expanded to the Short-Lived Fission Product Facility. The ${ }^{133} \mathrm{Xe}$ facility was added 
at about that time. Products and processes developed for sale included ${ }^{133} \mathrm{Xe},{ }^{131} \mathrm{I}$, and ${ }^{99} \mathrm{Mo}$. The ${ }^{133} \mathrm{Xe}$ operation continued through 1980, and the Short-Lived Fission Product Program was discontinued in 1985.

The ion-exchange columns were removed in the early 1960s. The upper three floors were converted to target fabrication facilities in the mid to late 1960s. Target fabrication was a full-cost recovery program at that time. Water-shielded cells were installed on the first floor in 1964 for the curium source fabrication program of Space Nuclear Systems. The curium fabrication program was not a full-cost recovery isotopes program. The major contamination in this building is left from the curium processing, the source fabrication work, and the ${ }^{147} \mathrm{Pm}$ processing.

Building 3029-Source Development Laboratory: Building 3029 is located in the west-central area of the Isotopes Circle, southwest of Building 3047. The building is a single-story, steel-frame structure covered by corrugated metal siding. The floor area is $3,000 \mathrm{ft}^{2}$. Building 3029 was constructed in 1952 and originally contained a system of remotely operated barricades and a small manipulator cell (now called Cell 4). The facility was built as part of and has always been used in the Isotopes Program. Isotopes originally handled in the facility were ${ }^{192} \mathrm{Ir}$ (source fabrication) and small ${ }^{60} \mathrm{Co}$ sources. Major building operations included ${ }^{60} \mathrm{Co},{ }^{137} \mathrm{Cs},{ }^{90} \mathrm{Sr}$, and ${ }^{192} \mathrm{Ir}$ source fabrication.

The operating area contains four manipulator-type hot cells. Cells 1, 2, and 3 were used to process high-level beta/gamma sources; Cell 4 was used for short-lived materials and ${ }^{192} \mathrm{Ir}$ monitoring. The cell access area contains a ${ }^{60} \mathrm{Co}$ storage and irradiation area known as the ${ }^{60} \mathrm{Co}$ garden. The ${ }^{60} \mathrm{Co}$ garden has been emptied and is part of the isotopes facilities deactivation.

Building 3030/3031/3118-Radioisotopes Production Laboratories C, D, and H: Buildings 3030 and 3031, the Radioisotopes Production Laboratories, were designed for limited production and development processing of reactor-produced beta/gamma-emitting radioisotopes for industrial, medical, and research applications. Building 3118 was constructed by enclosing the space between Buildings 3030 and 3031 and covers the access doors to the cells in these buildings. These buildings are located in the west-central area of the Isotopes Circle and north of Building 3038.

Chemical processing of a wide variety of radioisotopes has been carried out in the single hot cell of Building 3030. Primarily, these were irradiated targets from the High-Flux Isotope Reactor, the Oak Ridge Reactor facilities, and the 86-in. cyclotron.

Building 3030 was being prepared for a proposed ${ }^{90} \mathrm{Y}$ facility when the shutdown decision was made. Prior to that, the building had been used for processing ${ }^{153} \mathrm{Gd}$, a medical radioisotope.

Building 3118 is a steel-frame structure covered with corrugated aluminum siding that was erected by roofing and enclosing the space between Buildings 3030 and 3031 . Building 3118 provides access to the rear entry doors for the hot cells in Buildings 3030 and 3031, cask storage of some old radioactive sources, and temporary holding of contaminated waste.

Building 3032-Radioisotope Production Lab E and Building 3099 Storage Pad: The Radioisotope Production Lab E is housed in Building 3032, which is located in the central area of the Isotopes Circle, east of Building 3031. An ancillary facility, the Building 3099 storage pad, is adjacent to the east side of Building 3032.

The building is a steel-frame structure covered with aluminum siding. The floor space is about $1200 \mathrm{ft}^{2}$ with a total volume of about $20,000 \mathrm{ft}^{3}$. The facility has a laboratory containing five hoods on the north side of the building and an office area on the south side of the building. 
Building 3033-Radioactive Gas Processing Facility: The tritium and krypton production facility is housed in Building 3033, which is located in the central area of the Isotopes Circle, northeast of Building 3038. This building contains two separate radioisotopes processing systems for handling gaseous ${ }^{3} \mathrm{H}$ and ${ }^{35} \mathrm{Kr}$. An ancillary facility, the Building $3093 \mathrm{Krypton}$ Storage Cubicle, is adjacent to the west side of Building 3033.

The krypton process cell consists of a composite-shielded enclosure made of steel plate overlaid with lead supported by a concrete wall at the bottom. Part of the enclosure houses the in-process storage tanks.

Building 3033-A-Radioactive Production Laboratory Annex: Building 3033-A (Annex) was used to house and contain the facilities for the production, loading, welding, and decontamination of neutron dosimeter materials as well as the weighing and packaging of milligram to gram quantities of auctioned materials for research applications. The building does not contain a hot cell and was used only for low-level radioactive operations in glove boxes and one hood. The glove boxes and hood have been removed from the building. Building 3033-A is located in the central portion of the Isotopes Circle, south of Building 3047. It is a metal structure erected by bridging the space between Buildings 3033 and 3034 and using their walls for support.

Building 3033-A, which was constructed in approximately 1960, included two operating areas: a small one for ${ }^{14} \mathrm{C}$ production at the south end of the building operated by the Radioisotopes Department and the larger, main operating area for research materials preparations performed by Isotopes Research Materials Laboratory personnel. In the early 1980s, Isotopes Research Materials Laboratory personnel decontaminated and decommissioned the ${ }^{14} \mathrm{C}$ facility, including removal of the underground dissolver tank, and converted this area for storage.

Building 3034-Radioisotope Services Building: The Radioisotope Area Service facility is housed in Building 3034, which is located in the east end of the Isotopes Circle, adjacent to Building 3033-A. This facility was used as a field shop for the Plant and Equipment Division in supporting past isotope production operations in other facilities. No handling of radioactive materials has occurred in this building.

Building 3038-Isotopes Materials Laboratory, Radioactive Packaging and Shipping Facility: Recent uses of Building 3038 include the study of transuranic elements, fabrication of alpha- and neutron-emitting targets and sources, shipment of radioisotopes, and production of ${ }^{90} \mathrm{Y}$ for medical uses. The building, which is located on the southwest corner of Isotopes Circle, is a masonry and steel-frame structure. It is divided by concrete block interior walls into three separate facilities: 3038-E, 3038-M, and 3038-AHF.

The section of the building called 3038-M has always been the radioactive shipping operation for ORNL. Most of the shipments were for the isotopes sales program, but shipments of radioactive materials from other ORNL groups were also handled here. The radioactive shipping operations have now been relocated to another ORNL facility.

The analytical chemistry laboratories supporting isotopes sales were located in the east end until 1976. When the analytical function was transferred to other ORNL facilities, the east end was converted into an isotopes production and development facility.

Building 3047-Radioisotopes Development Laboratory: The Radioisotopes Development Laboratory, Building 3047, is a three-story, steel-frame building with concrete block exterior and interior walls. It is located in the north-central area of Isotopes Circle. Building 3047 is joined to the 
Isotopes Technology Building, Building 3047-A. Because they have individual ventilation systems and are separated by at least two sets of double doors, they are considered separate buildings. (Building 3047-A, which contains administrative offices, is not part of the deactivation plan).

The Radioisotopes Development Laboratory houses four high-level beta-gamma cells, one alpha hot cell, seven laboratories for handling low-level materials, a decontamination room, offices, and service areas.

Building 3517-Fission Product Development Laboratory: Building 3517, the Fission Product Development Laboratory, was constructed (1) to recover long-lived fission products (e.g., ${ }^{90} \mathrm{Sr},{ }^{137} \mathrm{Cs}$, and ${ }^{144} \mathrm{Ce}$ ) from aqueous wastes generated in reprocessing irradiated reactor fuel elements; (2) to purify feed materials from other DOE sites; and (3) to prepare radioactive sources. It is located in the central ORNL site, southwest of the Isotopes Circle facilities.

The Fission Product Development Laboratory contains manipulator and process cells for producing radioactive sources and associated operating, service, office, and personnel access areas.

Building 7025-Tritium Target Preparation Facility: Building 7025 is located about 1.4 miles northeast of the central ORNL site. It is within the perimeter fence of the ORNL 7000 area but isolated from other buildings.

The building was used to fabricate titanium tritide targets, prepare metallurgical samples for helium embrittlement studies, and prepare oxide thin films.

\section{Accomplishments}

Removal Site Evaluations continued for the 19 AOCs in the Nuclear Material and Facility Stabilization Program at ORNL.

\section{Concerns}

None.

\section{Scheduled Activities for Next Quarter}

Activities will continue on the Removal Site Evaluations for the 19 AOCs in the Nuclear Material and Facility Stabilization Program at ORNL.

\subsubsection{Oak Ridge Y-12 Plant RmSE Status}

No AOCs have been identified at the Y-12 Plant.

\subsubsection{Other Oak Ridge Reservation Areas RmSE Status}

No AOCs have been identified in these areas. 


\subsection{ER PROGRAMMATIC ACTIVITIES}

The CERCLA process at the ORR is dynamic in nature in that DOE is continually improving the process by modifying strategies, plans, and procedures to incorporate new ideas and new information. These activities are conducted in addition to the investigatory and cleanup actions taken at specific AOCs on the ORR.

\subsubsection{Oak Ridge Environmental Information System}

\section{Description}

The Oak Ridge Environmental Information System (OREIS) is a standardized, quality-assured, and configuration-controlled environmental information management system created to support DOE-ORO environmental programs. It is composed of hardware and commercial and customized software providing a user interface and analytical tools, a relational data base for environmental measurements data, a geographic data base for geospatial data, and supporting documentation. OREIS fulfills DOE-ORO's environmental information management obligations under an enforceable FFA. The basic mission of OREIS is efficient retrievability and long-term (greater than 3 years) retention of DOE-ORO environmental data. Its primary users include DOE, TDEC, EPA, and their contractors and subcontractors. Data in OREIS are available to other agencies and the public.

The OREIS project was initiated in September 1990, and the baseline production version of the system (OREIS V2.1) was released in June 1994. Since that time, OREIS has amassed approximately $1,500,000$ records of environmental measurements data and contains available remote sensing and base map data. The types of environmental data incorporated in OREIS include known-quality measurements data from the following environmental media: groundwater, well construction, surface water, sediment, soil, air, and biota. Types of available remote sensing data include gamma contour, predawn thermal, natural color, color infrared, and multispectral scanner for various areas. Site composites of the new base map data prepared from recent flyovers of DOE-ORO sites and surrounding areas contain such coverages as roads, buildings, utilities, water drainage, and contours.

The scope of OREIS includes consolidating data derived from or used to support environmental restoration, compliance, and surveillance activities at Oak Ridge, Tennessee, Portsmouth, Ohio, and Paducah, Kentucky. Additionally, it includes providing the analytical tools and user interface needed to access and analyze the data. The OREIS data bases also contain metadata on data quality, which enables end users to analyze the appropriateness of the data for secondary uses. The scope of OREIS does not include providing the functionality to perform project-specific activities, such as sample tracking, data entry of field results, or maintaining records on calibration of equipment; nor does the scope include providing project control capabilities, such as cost accounting or milestone tracking. These functions are provided by other computer systems.

\section{Accomplishments}

\section{Web-Based User Interface for PC Users}

OREIS staff continued the prototyping effort for the OREIS web-based user interface. A group of representative users from DOE, TDEC, and ER project data managers was created to review progress and provide feedback. Two meeting were held in January, and feedback from these meetings has resulted in significant improvements to the interface. User meetings will continue until the interface is completed. 
Prototypes of textual data base reports, data base views, geospatial displays, and a reports/view selection framework have all been completed. Prototypes were based upon feedback received from representative users during December 1995 and January, February, and March 1996.

\section{Transmission of Compliance Data to OREIS}

The technical specifications for transferring air emissions data to OREIS were approved and the document (ES/ER/TM-164) was released.

\section{Restructure of the OREIS Model}

Changes for the Phase II restructure of the OREIS data model were implemented on January 16, 1996.

The revised data dictionary for OREIS (ES/ER/TM-1 16/R1) was issued.

\section{OREIS Operations Statistics}

As of March 27, 1996, OREIS had 158 registered users. The OREIS database contains $1,464,536$ records and includes data from four of the five DOE-ORO facilities.

\section{Concerns}

None.

\section{Scheduled Activities for Next Quarter}

Provide electronic data for FFA Appendix E updates.

Continue to load data and support environmental information management activities.

Provide enhancements to the OREIS data model to accommodate additional compliance and surveillance and biological data.

Load Y-12 well construction and ground water measurements data.

Work with the Toxic Substances and Disease Registry to provide necessary OREIS data for the Clinch River OU.

\subsubsection{Remote Sensing and Special Surveys Program}

\section{Description}

Remote sensing technologies provide efficient means for acquiring data for site identification and characterization, change detection, regional and local monitoring, and for acquiring updated information to support geographic data bases (e.g., facility data, land cover, topography). The objectives of the Remote Sensing Program are to promote and manage routine examinations of the ORR and associated off-site areas and to process and analyze remotely sensed data for assisting in environmental restoration site characterization and cleanup. Surveys will occur on a biannual basis with selected remote sensing surveys as needed during other times of the year for site-specific studies. The biannual approach provides an effective means for early detection of environmental 
problems that may develop as waste containment vessels degrade, and it also aids in monitoring improvements gained from restoration efforts and cleanup activities.

\section{Accomplishments}

A presentation was made to the Site Specific Advisory Board on ER Remote Sensing and Base Mapping activities in Oak Ridge. The presentation addressed the various types of data (aerial photography, gamma radiological surveys, the Base Map program, multispectral scanner and predawn thermal data, and geophysical magnetic and electromagnetic data) and gave an overview of the uses of each data type.

The following documents Natural Color Aerial Surveys of the ORR 1992-1994 were issued: Overview of Data Processing and Analysis by the ER Remote Sensing Program, Fiscal Year 1995, (ER/ER/TM-166); Daytime Multispectral Scanner Aerial Surveys of the ORR 1992-1994: Overview of Data Processing and Analysis by the ER Remote Sensing Program, Fiscal Year 1995, (ER/ER/TM-170); and Predawn Thermal Infrared Aerial Surveys of the ORR, 1992-1994: Overview of Data Processing and Analysis by the ER Remote Sensing Program, Fiscal Year 1995" (ER/ER/TM-168).

The Remote Sensing Program initiated the integration of various remote sensing data sets for the Melton Valley watershed, with particular emphasis on WAG 5. The integration employs aerial photography, multispectral scanner imagery, and airborne geophysical surveys, with emphasis on waste site and surface hydrology characterization.

\section{Concerns}

None.

\section{Scheduled Activities for Next Quarter}

Analyze remote sensing data to determine rooftop integrity using national technical means.

Finalize ER site selection, and begin data analysis for geophysical anomaly review.

Complete the integration and analysis of all available remote sensing data for the Melton Valley watershed.

Continue review of classified remote sensing data for ER characterization, clean-up, and monitoring benefits.

Complete the final report on threatened and endangered vascular plant species on the ORR.

Complete the final report on threatened and endangered vertebrate animal species on the ORR. 


\subsubsection{Risk Assessment}

\section{Description}

A risk assessment, as defined in the DOE-ORO Interim Policy Guidance on Environmental Restoration Risk Assessment Initiation, Implementation, and Interaction, is the process of identifying, defining, and characterizing the adverse consequences of exposure to hazardous and radioactive materials. At the ORR, risk assessment includes the performance of a baseline risk assessment, refinement of preliminary remediation goals, and risk evaluation of remedial alternatives. Risk assessment may have both a human health risk assessment component and an environmental risk assessment component, whereby the human health risk assessment identifies, analyzes, and characterizes adverse health effects in human receptors, and the environmental risk assessment identifies, analyzes, and characterizes adverse impacts on other environmental receptors (i.e., local flora and fauna, etc.).

\section{Accomplishments}

The Role of Risk Assessment at DOE-ORO, (ES/ER/TM-180) was completed. This document defines the current risk assessment strategy to be implemented at the ORR and supersedes the previous risk assessment strategy document (ES/ER/TM-58).

Preparation was completed on the Quantitative Uncertainty Analysis of Superfund Residential Risk Pathway Models for Soil and Groundwater: White Paper.

The responses to regulatory comments were issued to DOE for the Preliminary Assessment of the Ecological Risks to Wide-ranging Wildlife Species on the Oak Ridge Reservation (DOE/OR/01-1407\&D1). As agreed upon in the December 5 FFA Project Managers' Meeting, these responses will not be incorporated into the D2 version of this document until the end of the fiscal year after the FY 1996 sampling results are received and the associated interpretations have been developed.

Preparation was completed on the Preliminary Remediation'Goals for Use at the U.S. Department of Energy (DOE) Oak Ridge Operations Office (ES/ER/TM-106/R1).

Preparation was completed on the Spatial Analysis and Decision Assistance code and user's guide. The Spatial Analysis and Decision Assistance provides the user with a host of powerful spatial statistical techniques that will aid in the remedial decision making process.

\section{Concerns}

None.

\section{Scheduled Activities for Next Quarter}

None. 


\subsubsection{Federal Facility Agreement Implementation}

\section{Description}

Section 120 of CERCLA requires federal facilities listed on the NPL to enter into an FFA with EPA. The ORR was added to the NPL in the fall of 1990. Subsequently, DOE, EPA, and TDEC entered into this agreement. The primary purpose of the FFA is to establish a procedural framework and schedule for investigating and remediating contaminant releases at a site (the ORR) that pose a threat to human health and the environment.

\section{Accomplishments}

Appendix $C$ was approved and transmitted on February 9, 1996, reflecting the comments received from EPA and TDEC.

Appendix E was approved and transmitted on February 9, 1996, and reflected changes in milestone dates.

Appendix E was revised to identify a change in the milestone date for the LEFPC Phase II Remedial Design Report to April 10, 1996.

Comments to the Site Management Plan (Rev. 4) were provided by EPA and TDEC.

A quality assurance assessment of the FFA controlled copies was initiated.

Activities for the preparation of the ORR Remediation Effectiveness Report were initiated.

The Administrative Record index transmittal operating instructions were completed.

The DOE facility operating instructions were completed.

Approval was received from the FFA parties regarding modification language in funding of priorities and scheduling in the FFA.

\section{Concerns}

None.

\section{Scheduled Activities for Next Quarter} FFA.

Submit public notice for FFA modifications regarding funding priorities and scheduling in the

Continue preparation of the ORR Remediation Effectiveness Report.

Submit the Site Management Plan (Rev. 5) to the regulators.

Complete the quality assurance assessment of the FFA controlled copies.

Complete the annotated report formats for the EE/CA and the Remedial Design Work Plan. 


\subsubsection{NPL Footprint Reduction Program}

\section{Area of Concern}

\section{The ORR}

\section{Description}

$\mathrm{DOE}$ is identifying lands and buildings on the ORR can be determined to the satisfaction of the EPA and the TDEC that no action and that those lands and buildings can be conditionally released from CERCLA requirements. This activity is called the "footprint reduction" task in reference to the final outcome of reducing the size and configuration of the area of the ORR designated as part of the National Priorities List (NPL) site.

A review process of all lands on the ORR for the purpose of identifying areas that have no indication of previous waste disposal activities and that are not otherwise known or suspected of being contaminated will be developed and conducted with the participation of TDEC and EPA. The process will use information from previous, ongoing, and future site evaluations; historic and current aerial photographs and specialized surveys; other historic and current records; personal recollections; and ground verification. Information gathered in the review process will be used to identify areas and facilities with no present or future funded use by DOE and which may qualify for removal from the NPL.

Candidate sites are evaluated for deletion using the CERCLA review process as described in Section 120(4)(A) of the CERCLA statutes. The goals for the program are the deletion of 6,000-8,000 acres in FY 1996, 10,000-12,000 acres in FY 1997, and 4,000-6,000 acres in FY 1998.

\section{Accomplishments}

A total of 16 areas have been identified for preliminary evaluation for deletion from the NPL; these sites compose approximately 24,000 acres of the ORR.

The preliminary evaluation of one modeled site (Number 14), under partnership with TDEC, has been completed. Documentation will be provided to the FFA parties for approval.

\section{Concerns}

None.

\section{Scheduled Activities for Next Quarter}

Present status of NPL Footprint Reduction activities to the FFA Project Managers' Meeting in April.

Complete all FY 1996 preliminary investigations of candidate sites.

Begin preparation of the summary report for the preliminary investigations. 


\subsection{LIQUID LOW-LEVEL WASTE TANK STATUS}

Although the FFA addresses the entire ORR, specific requirements are set forth for the LLLW tanks at ORNL. LLLWs have been collected at ORNL since 1943 in tank systems used for storage, transfer, and neutralization. The stated objective of the FFA as it relates to the tank systems (Appendix F) is to ensure structural integrity, containment, detection of releases, and source control pending final RA at the site. The FFA requires that leaking LLLW tank systems be immediately removed from service. It also requires that LLLW tank systems that do not meet the design and performance requirements established for secondary containment and leak detection be either upgraded or replaced. Out of service tanks will be remediated.

\subsubsection{Active LLLW Tanks}

Area of Concern

Active LLLW Tanks (FFA Appendix F)

Description

Activities for Category A, B, and C tanks are reported in this section.

\section{Accomplishments}

Installation of cathodic protection equipment on Phase II Systems 19 (Building 7830 to Tank T-13) and 21 (Building 3517 to Valve Box 2) was completed.

Performance of monthly leak testing on 13 active, Category C LLLW tanks at ORNL was continued. The one-time use period for Tank W-12 ended in October and is therefore no longer a part of the testing program.

Three enhanced volume balancing leak tests were performed.

A composite sample of the ion exchange resin used to treat three types of electropolishing solutions generated at the Irradiated Materials Examination and Testing facility was sent to Analytical for Toxicity Characteristics Leaching Procedure extraction and metals analysis. The results indicated that the ion exchange resin used in the future to treat electropolishing solutions would have a low likelihood of being considered a hazardous waste.

The final version of the document review record for the Structural Integrity Assessments for the Category C LLLW Tank Systems at ORNL was submitted to EPA and TDEC on January 2, 1996. EPA and TDEC have agreed to the changes to the D1 version of the Structural Integrity Assessments document as discussed in the document review record based on their letters dated January 25, 1996, and February 14, 1996, respectfully.

\section{Concerns}

None 


\section{Scheduled Activities for Next Quarter}

Issue the D1 version of the Implementation Plan for Liquid Low-Level Waste Tank Systems for FY 1996.

Initiate and complete installation of cathodic protection equipment on Phase II System 9B.

Initiate preparation of annual reassessment of the Structural Integrity Assessments.

\subsubsection{Inactive LLLW Tanks}

\section{Area of Concern}

Inactive LLLW Tanks (FFA Appendix F)

\section{Description}

Activities for Category D tanks are reported in this section.

\section{Accomplishments}

Procurement activities began on the proposal for Ionics Resource Conservation Company to provide engineering design and cost analysis on the removal of PCBs from Tank WC-14 using their B.E.S.T. ${ }^{\circledR}$ process for PCB removal from soils, sediments, and sludges.

The initial on-site data collection effort was completed for evaluating methods of removing sludges from various tanks as part of the remediation effort. Tanks WC-11, WC-14, WC-20, and $2026 \mathrm{~A}$ have been chosen as case studies representative of most of the tank system configurations and sludge characteristics that will be encountered.

Change pages for Tank WC-7 were issued for the Waste Characterization Data Manual for Inactive LLLW Tanks and the Risk Characterization Data Manual for Inactive LLLW Tanks to include results based on sampling performed just prior to the removal of service of Tank WC-7.

Inactive LLLW Tank LA-104 was removed from the vault beneath Building 3047, and placement of the tank in a container took place on February 7. Plans are to dispose of the tank by melting, pending completion of final analysis and documentation.

The approved design package for the isolation of inactive LLLW Tank WC-7 was issued January 26, 1996. Field activities are scheduled to begin in early April.

The approved design package for the isolation of inactive LLLW Tank WC-4 was issued on March 29, 1996.

The report summarizing the Group 6 inactive tank characterization study, Sampling and Analysis of Inactive Radioactive Waste Tanks W-17, W-18, WC-5, WC-6, WC-8, and WC-11 through WC-14 at ORNL, ORNL/TM-13017, was completed.

\section{Concerns}

None. 
Scheduled Activities for Next Quarter

Complete design activities on the 4500 Area Isolation.

Complete field activities for isolating LLLW Tank WC-7 from connected facilities and systems.

Complete design activities for Tank 4501-P, the remaining inactive LLLW tank scheduled for isolation in FY 1996.

Perform remediation of Tank WC-7 (by filling with a grout slurry) as a maintenance action during isolation activities. 



\section{OTHER REGULATED ACTIVITIES}

These activities are regulated under a requirement other than the FFA, however, they are reported here to inform the reader of activities at AOCs under the FFA.

\subsection{K-25 RCRA Closures}

Area of Concern

K-1417 Drum Storage Yard, K-1419 Sludge Fixation Facility

\section{Description}

This project consists of the removal of above- and below-ground structures associated with two former waste management facilities. The RCRA closure is being performed under the guidance of the Decommissioning Project Plan for the K-1417-A and K-1419 RCRA Closure Plan (DOE/OR-1076/V1\&D1). Closure of the K-1419 Sludge Fixation Facility will occur over the period from FY 1996 to FY 1997 and encompasses the decontamination of hazardous waste materials (where necessary) and the removal of equipment and above-grade structures (except storage tanks F-4030 and F-4170). The K-1417 Drum Storage Yard closure has been divided into two tasks: the " $A$ " section of the Drum Storage Yard will be closed during FYs 1996-1997, and the "B" portion will be closed by March 1999.

Field activities are presently underway and being performed in accordance with the K-1419 Sludge Fixation Facility and the K-1417-A Drum Storage Yard Demolition/RCRA Closure Project Performance Specification, July 1995.

\section{Accomplishments:}

Approximately $40 \%$ of the K-1419 facility has been demolished; approximately 53,000 pounds of scrap metal has been dispositioned as radiologically free material.

\section{Concerns:}

None.

\section{Scheduled Activities for next Quarter:}

Closure activities at the two facilities will continue. 


\subsection{Y-12 RCRA CLOSURES}

\subsubsection{Y-12 Plant RCRA Closures}

\section{Area of Concern}

Garage Underground Storage Tanks, Interim Drum Yard, Diked Tank Storage Facility

\section{Description}

This subproject consists of three release sites: (1) the Building 9409-5 Diked Tank Storage Facility, (2) the Garage Underground Storage Tanks, and (3) the Interim Drum Yard.

The Garage Underground Storage Tanks were part of an on-site facility for servicing motor vehicles. This facility included a gas station with associated underground fuel tanks, underground piping, dispensing pumps, a building, and ancillary fixtures. Two tanks were previously used to store unleaded gasoline (a 20,000-gal tank) and leaded gasoline (a 10,000-gal tank). The tanks were subsequently diverted from their initial use to the storage of waste oils containing the spent solvents perchloroethylene and ${ }^{113}$ Freon and measurable quantities of PCB and uranium. A third empty tank in the same dirt emplacement with the two RCRA tanks contained waste oil that was not hazardous as defined by current regulations.

Clean closure of the tanks began in 1988 with the excavation, decontamination, and removal of the tanks; the sampling of surrounding soil; and the removal of contaminated soil. As a subproject, the three contaminated tanks were cleaned and removed in early 1994. The RCRA closure package-which includes closure certification by the independent registered professional engineer, the closure summary report, and supporting closure documentation-has been prepared and issued, and clean closure of this site has been approved by the state regulators.

The Building 9409-5 Diked Tank Storage Facility was a RCRA-permitted, outdoor, concrete, diked area with a capacity of approximately 238,000 gal. This facility was constructed in 1942 as a four-cell cooling tower basin, but it was modified in 1980 for use as a secondary containment facility for tanks and drums of liquid waste. These tanks and drums contained, at various times, liquid waste coolant, solvents, and waste oils-all of which may have contained PCBs. Some of the waste liquids stored in this facility were known to have contained uranium and beryllium. Chromium may be present as a result of the water treatments used during cooling tower operations. All tanks have been removed from the facility, and a closure plan revised according to state regulatory comments has been approved this quarter.

The Interim Drum Yard, west of Building 9720-32, was a RCRA, outdoor, tented storage facility for containerized hazardous waste. Drums were stored on wooden pallets placed on gravel lined with a plastic tarp covering native soil. Wastes stored at the facility consisted of mercury, metals, acrylonitrile, methylene chloride, organics, ${ }^{113}$ Freon, cyanide, PCBs, uranyl nitrate, penetrant solution and emulsifiers, asbestos, and sodium hypochlorite.

Soil sampling indicated that the underlying surface soil and gravel were contaminated. All waste stored at this site was shipped off site for final disposal or transferred to a RCRA-permitted storage facility on the ORR. The tent structures and diking were also removed to prepare the site for sampling and characterization activities. Analytical results indicated that the soil in two areas had some contamination above RCRA clean closure criteria for cadmium and mercury. Excavation of these two areas is the focus of the work plan. 


\section{Accomplishments}

The RCRA closure work plans for the Interim Drum Yard and the Diked Tank Storage Facility were approved. Completion of these projects according to these work plans will result in clean closures of these AOCs. Closure activities at the Interim Drum Yard and the Diked Tank Storage Facility began in January 1996.

\section{Concerns}

None.

\section{Scheduled Activities for Next Quarter}

Closure actions will continue through the fourth quarter of FY 1996.

\subsubsection{Kerr Hollow Quarry RCRA Closure}

\section{Area of Concern}

Kerr Hollow Quarry

\section{Description}

Kerr Hollow Quarry was a former rock and gravel quarry that was abandoned in the late 1940s when it filled with water. From at least 1951 until 1988, the Y-12 Plant and ORNL used Kerr Hollow Quarry for the treatment of water-reactive and corrosive materials and potentially explosive chemicals and for the disposal of empty compressed gas cylinders when personnel safety was of concern. Kerr Hollow Quarry was not intended for use as a hazardous waste storage or disposal facility but was used as a treatment facility as registered on the RCRA Part A permit. The facility was placed in interim status under RCRA, and treatment operations ceased in 1988. Kerr Hollow Quarry discharged through Outfall 301, and this outfall was monitored in accordance with NPDES Permit TN 0002968. The permit required monitoring the Kerr Hollow Quarry outfall following a treatment operation, with results reported quarterly to TDEC. A RCRA closure was completed on this project, which included underwater breaching of containers to ensure complete reaction of reactive materials and removal of all visible containers from the quarry. Based on the actions taken under RCRA, no additional investigations were conducted under CERCLA, and a CERCLA ROD was approved in the fourth quarter of FY 1995. The ROD requires surface water monitoring at the former NPDES Outfall 301. This monitoring will be conducted semiannually. In addition, the ROD defers groundwater monitoring requirements to the RCRA postclosure permit, which was recently issued for review. Until the permit is issued, detection monitoring at the surrounding groundwater wells will continue quarterly. In the future, summarized monitoring results will be reported in the annual Remediation Effectiveness Report for the ORR and in the Chestnut Ridge Hydrogeologic Regime Groundwater Quality Report.

\section{Accomplishments}

The draft RCRA postclosure permit has been issued for review. The public comment period closes May 13, 1996. 
Concerns

None.

Scheduled Activities for Next Quarter

A public meeting will be scheduled as necessary to discuss the RCRA postclosure permit.

\subsection{REDUCTION OF MERCURY IN PLANT EFFLUENTS}

\section{Area of Concern}

UEFPC, LEFPC, Mercury Use Areas

\section{Description}

From 1955 through 1963 at the Y-12 Plant, a column-exchange process involving large quantities of mercury was employed in many of the major process buildings to separate lithium isotopes. Since that time, Mercury Use Areas, including buildings and surrounding contaminated soils, have been designated as possible sources of mercury contamination because of known, suspected, or presumed releases. These areas are the focus of RMPE, which is a cooperative effort between the Clean Water Act and CERCLA compliance organizations. The area of investigation includes soils surrounding and drainages associated with the following buildings and adjoining areas: 9201-2, 9201-5, 9202, 9204-4, 9733-1, 9733-2, and mercury flask storage areas and deflasking facilities. Subprojects in RMPE are described below.

Mercury-Use Buildings Source Eliminations Encouraging reductions of mercury loading to the creek have been realized in the past from sewer upgrades and pipe reroutes. Additional pipe reroutes, where mercury-contaminated storm drains and sumps have been bypassed by the installation of new piping, provide for clean transport of water from the building. Source elimination work has been completed in Buildings 9204-4, 9201-2, 9201-5, and 9201-4. In addition, source elimination work in Building 9201-5 has been completed to consolidate sump water from 9201-5 and 9201-4 into an existing underground tank. The routing of this sump water to the tank provided isolation of the sumps and allows monitoring of the remaining discharges from these buildings and verification of the pipe rerouting and replacement effort. The tank will serve as the interface point for the Central Mercury Treatment System to pick up the sump water for treatment when it becomes operational. Source elimination in Buildings 9201-4 and 9204-4 was also completed in October and November 1995 well ahead of the NPDES compliance schedule.

Interim Mercury Treatment Unit An on-line effluent treatment process has been installed in Building 9201-2 to remove mercury from Y-12 Plant storm water. A demonstration treatment process with associated pumps and piping was originally installed in 1994 to collect the contaminated sump water for treatment, and plans are in place for an upgrade to a permanent system and achieve more throughput. Approximately 7,000,000 gal of water have been treated at the Interim Mercury Treatment Unit in Building 9201-2 through the end of March 1996. The operation of this unit in conjunction with the source elimination work in Building 9201-2 has resulted in a reduction of mercury loading from $9201-2$ to UEFPC from $3.25 \mathrm{gal} / \mathrm{d}$ to less than $0.5 \mathrm{gal} / \mathrm{d}$. The source elimination work in 9201-2 resulted in the total removal of water discharging through Outfall 49. 
Central Mercury Treatment System The mercury-contaminated waters from the Mercury Use Building sumps (9201-4, 9201-5, and 9204-4) will be collected, and long-term treatment will be performed at the Central Mercury Treatment System. The system will be housed at the existing Central Pollution Control Facility. Demolition at the Central Pollution Control Facility to make room for the Mercury Treatment Facility is underway. Construction and procurement activities are also underway.

Mercury Air Stripping Test Facility at Outfall 51 This facility is a pilot operation designed to investigate the potential for removal of mercury from contaminated groundwater. Outfall 51 is a spring discharging to UEFPC south of Building 9201-2. A portion of the flow from this outfall is being collected, flowed through an air stripper, filtered, and discharged to UEFPC. The facility began operation in August 1995, and investigative efforts are planned to continue for 3-6 months.

\section{Accomplishments}

Overall, the pace of mercury activities at the Y-12 Plant is ahead of the compliance schedules in the NPDES permit, and new opportunities are being recognized for achieving additional mercury reductions. These opportunities were not felt to be achievable several years ago.

A test plan for the Mercury Air Stripping Test Facility is being prepared to ensure adequate data are collected to validate the process and eventually scale up to a full treatment system.

Sampling of Outfall $47 / 48$ shows that mercury loading from this outfall has fallen below the action level as a result of the Building 9202 sanitary sewer rerouting job.

\section{Concerns}

Concern: Despite the tremendous progress made in RMPE, the NPDES permit requires UEFPC to be at state water quality standards for mercury on the last day of the permit. This is unattainable with current technology. Impact: Without technology advancements, the NPDES requirements will not be met. Action: An appeal to the NPDES permit has been submitted. The ongoing CERCLA activities for the UEFPC CA will be considered a vehicle to obtain risk-based relief from the NPDES permit requirements. Under the current RI/FS schedule, the UEFPC CA ROD will not be complete by the last day of the permit. The project team is preparing a white paper proposal for submittal to the regulators for agreement to a potential interim action for mercury.

Concern: The pilot mercury air stripper for Outfall 51 is the subject of continuing and focused evaluation and refinement of operating parameters. Impact: Compliance with requirements of the NPDES permit is being evaluated. Action: TDEC is reviewing a proposal for the use of chemical reductants to improve removal efficiencies and to process a waiver or alternate concentration limit for the system.

\section{Scheduled Activities for Next Quarter}

Continue RMPE treatment facilities. Currently, the Interim Mercury Treatment Unit in Building $9201-2$ treats $20 \mathrm{gal} / \mathrm{min}$. A project is in the planning stages to upgrade the unit to a permanent system with the capacity to treat $30 \mathrm{gal} / \mathrm{min}$. The upgraded unit is expected to be in service by the end of April.

Continue demolition in Building 9623 to support the Central Mercury Treatment System. 


\section{REMEDIAL ACTION CONTRACTOR ASSIGNMENTS}

Each FFA quarterly report includes a listing of the identity and assigned tasks of each of the DOE contractors performing work under the FFA. The primary contractors-Energy Systems and Jacobs Engineering-will be performing work at all locations within the ORR. The following is included to satisfy this requirement.

\subsection{OAK RIDGE Y-12 PLANT}

American Technologies, Inc.-Quality assurance and assessment support for the UEFPC CA.

CACI:ASG-Project control support.

CDM Federal Programs Corp.-Technical support and integration for the RI/FS phase of UEFPC CA.

CKY, Inc.-Technical support with sediment sampling and risk assessment for UEFPC.

Camber Corp.-Quality assurance support for UEFPC CA.

DASKR LTD, Inc. - risk assessment support.

Highland Drilling, Co. - monitor well maintenance.

Parallax, Inc. - project control support.

Technics Development Corp.-Technical support for LEFPC.

TN \& Associates - technical support for the UEFPC.

University of Tennessee - soil and water studies for Bear Creek and multiport well sampling.

Foster Wheeler Environmental Corp.-Design contractor for multiple projects.

Gram, Inc.-General site characterization and preremedial design support to the UEFPC and Bear Creek CAs.

Jacobs Engineering (DOE prime contractor)-Preparation of decision documents.

MK-Ferguson-Construction management and support services.

Pacific Western Technologies, Ltd.-Project control support.

PAI-Project control support.

ParaMax, Inc.-Project control and support for UEFPC CA.

Science Applications International Corp.-Technical support and integration for the RI/FS phase of the Bear Creek CA.

\subsection{OAK RIDGE NATIONAL LABORATORY}

Advanced Sciences, Inc. (ASD)-Administrative support, field coordination, and technical integration.

Advanced Systems Technology - Waste characterization processing and transportation assistance. 
Analysas-Administrative support.

ATI-Structural integrity assessments for active LLLW tanks.

ATG-D\&D of the Waste Evaporator Facility.

Automated Sciences Group-Biological data analysis, support for management, and analysis and interpretation of biological data from laboratory and field studies.

Battelle Pacific Northwest Laboratory-Design and fabrication services for an ISV off-gas hood and filtration system.

Bechtel National, Inc. (Team members also include CH2M Hill; PEER; ERC, Inc.; and IT Corporation)-RI activities for WAGs 1, 5,6, and 10. Assessments will also be conducted of the inactive tanks as required by the FFA.

CDM Federal Programs-Preparation of a regulatory review and sampling and analysis plan for the WAG 6 performance monitoring activity.

CER-Assistance in preparing the WAG 6 well plugging and abandonment plan.

Colorado Logging COLOG — Logging and ambient and stress testing of wells at WAG 5.

Dr. David Daniel-Assistance in evaluating the suitability of soil for caps.

ECOTECH-Assistance in the analysis of surface water.

EDGE, Inc--Groundwater monitoring of wells.

Environmental Consulting Engineers-Preparation of remediation and postremediation monitoring plans for WAG 6 and monitoring in WAG 2 and WAG 5 removal action investigation.

ERC, Edge-Geotechnical tests.

ETE Consulting Ėngineers-Survey services.

Foster Wheeler-Remedial design activities.

Geotek Drilling-Drilling services.

Gilbert Commonwealth-Assistance with preparing cost account plans and project documentation such as project management plans, health and safety plans, waste management plans, current year work plans, and configuration control support documents. Valve replacement for active LLLW tanks.

Harco-Cathodic protection for active LLLW tanks.

H. Kent Hepworth, PE. Ph D.-Technical assistance with RAs in support of the WAG 6 facility manager.

Highland Drilling Company-Construction and well plugging and abandonment services.

H\&R Technical Associates, Inc.-Technical and administrative support in assembling reports, preparing minutes of meetings, and reviewing reports for active LLLW tanks.

Jacobs ER Team-Preparation of integrated RCRA/CERCLA/National Environmental Policy Act decision documents, including FSs, Proposed Plans, RODs, Environmental Assessments, Environmental Impact Statements, documents for interim actions, and cost estimates associated with these documents. Provision of technical support for the performance of RIs, assessments and investigations of off-site locations, and RA verification; support for DOE and Energy 
Systems community relations activities; and support for the adherence to requirements associated with the Administrative Record and performance of risk assessments.

JAYCOR-Sampling and analysis support for benthic macroinvertebrate samples from WOC and its tributaries (no longer supporting benthic macroinvertebrate samples).

JBF Associates-Technical Advisory Group support and appraisal of the Underground Storage Tank Program.

Kansas Geological Survey-Collection of seismic reflection data for WAG 10.

Knoxville College-Data base support and technical support for sample collections.

Lockheed-Analytical services.

MAC Tech-Implementation of data quality objectives for the Safer Program.

Midwest Technical, Inc.-Assistance in budgeting, planning, and cost tracking and provision of laboratory and field technical support.

MK-Ferguson-Construction management. Valve replacement/cathodic protection for active low-level radioactive waste tanks.

North Carolina State University-Assistance in biological monitoring and abatement tasks.

Northern Arizona University - Technical direction for surveillance and maintenance and WAG 5 cryogenic.

Oak Ridge Associated Universities-Field services coordination.

OGDEN-Geotechnical services as required to support the remedial design architect-engineer and the Performance Assessment Program.

Operational Technologies-Preremedial design support.

Pacific Western Technologies-Project control support.

Parallax-Project control support.

Peer Consultants-Administrative support (team member of SAIC).

Performance Development Corporation-Technical and administrative support for active LLLW tanks.

Pragmatics-Nuclear criticality safety reviews for MSRE.

SAIC-Monitoring coordination, performance assessments, and hydrologic modeling for the WAG 6 Performance Assessment Program.

SGN - Evaluating removal of sludges from various active LLLW Tanks.

Scientific Ecology Group SEG—Field demonstration on waste stabilization in burial trenches.

Solutions To Environmental Problems-Health and safety planning.

Southwest Research-Outside laboratory services.

S. M. Stoller Corporation-Administrative support.

Temp Systems-Assistance with administrative functions and surface water monitoring.

Tennessee Valley Authority Interagency Agreement-Technical supervision of FY 1992 drilling activities, including drilling three core holes and instrumenting them with multiport measuring 
systems (Westbay systems) and selecting monitoring intervals using core data, geophysical logs, and flowmeter data via the agreement.

TMA Eberline-Outside laboratory analytical services.

TN \& Associates-Operation and maintenance of the Close Support Lab and Field Operations Facility.

University of California-Assistance in biological monitoring and abatement tasks.

University of California Davis-Histopathological analyses of fish tissues.

University of Mississippi-Development of a special sensor for monitoring soil moisture and contaminant leaching.

University of Tennessee-Assistance in performing data collection; data compilation; development of performance criteria, maintenance programs, and quality assurance plans; and oversight of surface-water monitoring station upgrade activities.

U.S. Geological Service-Assistance in performing surface water monitoring.

Vista Research, Inc.-LLLW tank system leak testing methodology development.

Westinghouse Hanford Company-Procurement and delivery of a modified light duty utility arm for GAAT.

XI_Planning support for GAAT innovative technology development, testing, and development.

\subsection{OAK RIDGE K-25 SITE}

Barge Waggoner Sumner \& Cannon-Subcontractor to Engineering Department for site surveying.

Environmental Consulting Engineers-Continuous water level monitoring for the Groundwater Program.

Foster Wheeler Environmental-Home office Title III support and preparation of the Integrated System Test Plan and systems narrative and vendor manual document for the SW31 Spring Project.

Informatics-Project management support for the Groundwater Program.

Jacobs Engineering-Assistance in project scoping and work on the EE/CA, FS, Proposed RA Plan, and ROD for K-1070.

Kansas Geological Survey-Seismic reflection study for the Groundwater Program.

MK-Ferguson-Construction management of the Phase 2 Central Neutralization Facility upgrades.

Science Applications International Corp.-RI technical support, including field investigation, lab analysis, data validation, and preparation of the RI report. Remedial site evaluation support and preparation for the Groundwater Program. RI for K-1070.

U.S. Geological Survey-Stage gauge measurements and seepage runs along Mitchell Branch for the Groundwater Program documents.

PAI Corporation-Support for the production of integrated decision documents.

STEP-Support for the production of integrated decision documents. 
The University of Tennessee-Training and other support for the production of integrated decision documents.

United Science Industries-Support for the production of integrated decision documents.

\subsection{OTHER OAK RIDGE RESERVATION AREAS}

Camber Corp.-Quality assurance and statistical support for LEFPC.

Energy Systems-Business management, project management, and technical support for Freels Bend Area, SCF, LEFPC, Clinch River/Poplar Creek, and Lower Watts Bar Reservoir.

Jacobs Engineering-Project management and technical support for Lower Watts Bar Reservoir.

SENES Oak Ridge, Inc. - risk assessment and uncertainty analysis support for Clinch River/Poplar Creek.

Southwest Research Institute - laboratory services for David Witherspoon, Inc.

University of Tennessee Energy Environment and Resources Center-Technical leadership for RI activities for Clinch River/Poplar Creek.

\subsection{ENERGY SYSTEMS ER CENTRAL DIVISION}

CDM Federal Programs-Regulatory compliance support and waste analysis support on the Portsmouth project.

Ecotect Laboratory Services, Inc. - Laboratory sample analysis.

Ekotek Laboratory Services, Inc.-Radiological/analytical data analysis.

H\&R Technical Associates, Inc.-Consultation on cost/schedule control systems and groundwater data base management.

Lagos-FFA implementation support.

Lietzke Soil Services-Soil consulting services.

Lockheed Analytical Services-Chemical/analytical data analysis.

Lockheed Engineering and Sciences Company-Laboratory sample analysis.

Maxima Corporation-Project management.

Micro-Frame Technologies_-Off-site training and professional training support.

Premier-FFA implementation support.

SAIC-Site-specific plan support for the development of OREIS; training support; activity data sheet support; cost/schedule control system training; scheduling and technical support; waste management treatment, storage, and disposal analysis; analytical needs assessment; support services for preparation of the five-year plan; and data management support; FFA implementation support.

University of Tennessee-Soil characterization, hydrogeology, and data base management support.

University of Waterloo (Canada)_-Groundwater modeling. 


\subsection{JACOBS ENGINEERING}

Geraghty \& Miller-Environmental sciences and groundwater support for the production of integrated decision documents.

Lockwood Greene-Environmental engineering support for the production of integrated decision documents.

PAI Corporation-Support for the production of integrated decision documents.

STEP-Support for the production of integrated decision documents.

The University of Tennessee-Training and other support for the production of integrated decision documents.

United Science Industries-Support for the production of integrated decision documents. 
Please do not forward or discard this document.

If this address is not correct for the designated addressee, please return this document to the

ER Central Document Management Center Building K-1002, MS 7243

Lockheed Martin Energy Systems, Inc.

P.O. Box 2003

Oak Ridge, TN 37831 